\title{
LEANDRO MORATÍN EN ITALIA. LA COMMEDIA NUOVA (1795): TRADUCCIÓN, POLÉMICA TEATRAL Y APROPIACIÓN TEXTUAL
}

\author{
Franco Quinziano \\ Kyoto University of Foreign Studies (Japón)
}

\begin{abstract}
The Hispanist, critic and theatre translator Pedro Napoli Signorelli, has translated to the Italian language four of the five comedies of his friend, the famous Spanish dramatist Leandro Fernández de Moratín. The study examines the Italian translation of the Comedia nueva (1795), stressing on the process of "apropiación textual" that Signorelli carries out. Although the comedy is revealed respectful as much in the linguistic plane as in the one of the subjects and contents, Signorelli changes some dialogues in the ending scenes, moving partially away of the original text. Through these modifications he emphasizes some humorous and satirical characteristics of the personages. Above all else, conscious of the controversial intention of the piece, he perceives in the play of his Madrilenian friend a valuable occasion to continue and to update the lengthy cultural controversy and the personal battle against his adversaries, specially García de la Huerta, Ramón de la Cruz y and Llampillas.
\end{abstract}

\section{NAPOli Signorelli: hispanista, CRítico Y TRAductor teatral}

Los años que ocupan el último tercio del XVIII y los principios del XIX hacen referencia a uno de los momentos de mayor intensidad en el campo de las relaciones culturales hispanoitalianas. Sin desmerecer la importancia de los vínculos que estrecharon los jesuitas expulsos, afincados en la península italiana a raíz de la pragmática de expulsión de 1767, y la importante actividad que muchos de ellos desempeñaron en los más diversos campos del quehacer cultural, reconciliando ambas culturas en contacto, la relación ejemplar que Giovambattista Conti (1741-1820) y Pietro Napoli Signorelli (1731-1815) establecieron con varios literatos españoles, de modo especial con los dos Moratines, reflejan con toda probabilidad dos casos significativos de esta nueva fase que se ha abierto con la llegada al poder del tercer Borbón en 1759. Ahora bien, si la personalidad del véneto Conti constituye un punto referencia inestimable para la comprensión en clave comparada de la poesía española e italiana en el setecientos, el hispanista Napoli Signorelli, hombre de vasta cultura, espíritu curioso y fiel expresión del Illuminismo napolitano, se erige en una de las figuras emblemáticas para el estudio y la comprensión del amplio entramado que en campo teatral trazaron ambas penínsulas a lo largo de la segunda mitad de la centuria.

\footnotetext{
${ }^{1}$ Sobre la relación que el italiano entabló con Nicolás Moratín véanse Gies (1979: 33-38) y Quinziano (2002: 199-204); sobre el vínculo del dramaturgo napolitano con su hijo, el célebre comediógrafo Leandro, se remite en cambio a Mariutti Sánchez de Rivero (1960: 763-808) y a Quinziano (2001: 265-269; 2002: 201-231 y 2003: 253-255).
} 
Conviene recordar en primer lugar que la intensa actividad literaria que caracterizaba el Madrid de mediados de los años sesenta del XVIII favoreció la rápida inserción del erudito napolitano en la vida cultural de la ciudad del Manzanares. La crítica ha resaltado la favorable acogida, "piena di simpatia" (Bigi 1960: 590), tanto en los ámbitos cercanos a la Corte como en los más prestigiosos círculos culturales que ofrecía el Madrid de Carlos III y que, una vez, afincado Napoli Signorelli nuevamente en su ciudad natal, dejó en el ánimo del literato una grata nostalgia de los años transcurridos en la península ibéricą. De la hospitalidad y de las amistades cultivadas en aquellos años, como así también de las innumerables manifestaciones de estima y afecto que el napolitano recibió en Madrid dan cuenta su epistolario y los comentarios elogiosos que salpican algunos de sus textos, de modo especial su monumental Storia critica de' teatri antichi e moderni (1777), redactada en primera instancia, como el mismo autor nos confiesa, en lengua española En sus largos años en Madrid, que se prolongó por casi cuatro lustros, desde setiembre de 1765 hasta finales de 1783, el escritor napolitano perfeccionaría el estudio del castellano, idioma, según sus propias palabras, "rico, expresivo, majestuoso, (...) armonioso y noble" (Storia, VII: 3-4), que llegó a dominar con pericia filológica, ampliando al mismo tiempo sus estudios hispánicos, con particular atención al género dramático y a los autores del teatro áureo ${ }^{4}$.

La febril actividad cultural que caracteriza los años sesenta de la centuria le brindan al dramaturgo partenopeo la oportunidad de estrechar nuevas y decisivas relaciones personales y literarias, favoreciendo de este modo su rápida inserción en los círculos y en los ámbitos de debate y de producción cultural madrileño más prestigiosos de aquellos años. En dicha perspectiva el autor italiano fue urdiendo en Madrid una vasta red de contactos personales y literarios, en el que destaca el importante vínculo de amistad que estrechó con destacados intelectuales pertenecientes al círculo cultural aglutinado en torno a la figura señera de Nicolás Fernández de Moratín, con quien el crítico italiano mantuvo una intensa relación de

\footnotetext{
2 Sobre la estancia madrileña, de casi cuatro lustros, del crítico partenopeo, véase Quinziano (2003a) y su versión más extensa (2003b).

${ }^{3}$ Mininni (1914) recoge más de ciento sesenta cartas del napolitano, aunque hay que lamentar el hecho de que gran parte del nutrido epistolario de Signorelli de aquellos años, referido al período madrileño, como recuerda el mismo literato, se haya extraviado después de su definitivo regreso a Nápoles en 1783. El italiano lamenta la pérdida de su carteggio "per tanti anni continuato coi suoi più cari virtuosi amici", debido sobre todo a "l'incuria dei miei che trascurarono di custodir quelle carte, stimandole da me abbandonate" (Opuscoli Varii, I: 10), privándonos así de mayores detalles y de información valiosa sobre su larga experiencia madrileña.

${ }^{4}$ Durante su 'querida estancia' de casi dos décadas en Madrid, Napoli Signorelli escribió muchísimo entre las que descuellan su obra capital, la ya aludida Storia critica de' teatri antichi e moderni, varios textos de sátira y algunas piezas teatrales, como la Tirannia domestica, ovvero Rachele (1781), basada en el tema moratiniano de la libertad de la mujer y de la condición femenina y la premiada La Faustina (1778), encuadrada en el género de la 'commedia tenera' o 'lacrimosa', tan en boga en aquellos años. Esta última pieza sería traducida al español por Fermín del Rey, adaptador 'oficial' de las comedias de Goldoni, siendo representada sucesivamente en Madrid en el teatro del Príncipe, precisamente cuando más fuerte soplaban los vientos de la polémica que el italiano había entablado con García de la Huerta y Xavier Llampillas. La Tirannia domestica en cambio fue traducida tan sólo parcialmente por el mismo Leandro Moratín, quien volcó al español algunos pasajes correspondientes a la escena IX del cuarto acto; traducción que años más tarde el mismo crítico italiano habría de incluir en la última edición de su monumental Storia critica dei teatri (1813, X: 50-56). Aunque el dramaturgo español conocía perfectamente la lengua italiana, estos versos, hasta prueba contraria, constituyen la única traducción por él realizada -si bien incompleta-, y que hasta hoy nos ha llegado, de un texto italiano al español. Es posible consultar también la versión moratiniana de estos pasajes en el citado ensayo de Mariutti de Sánchez de Rivero (1960: 7957).
} 
amistad, proseguida, después de la prematura muerte del autor de La petimetra, y hasta sus últimos días, con su hijo, el célebre comediógrafo Leandro (Quinziano 2002).

La importante relación que el autor partenopeo estrechó con ambos dramaturgos españoles marcará su rumbo literario y estético, incidiendo de modo crucial en sus preferencias literarias y estéticas, de modo evidente por lo que respecta a sus ideas dramáticas y a su visión y concepción del teatro español, tanto por lo que atañe al drama áureo como a la producción teatral del setecientos. Si Signorelli guía a los dos Moratines en el estudio de los clásicos; don Nicolás primero y, sucesivamente, su hijo Leandro, "heredero de su numen", en palabras del napolitano (en Mininni: 343), aconsejan a su vez al italiano, informándolo sobre las virtudes y los aciertos del teatro clásico español, siendo evidente el influjo que ambos ejercieron sobre las ideas teatrales del literato italiano. La crítica (Mininni, Mariutti de Sánchez Rivero, Rossi y Soriano Pérez-Villamil, entre otros) han resaltado la importancia de esta doble relación, recordando cómo, gracias a las gestiones de su amigo Nicolás Moratín, el crítico napolitano había logrado entrar en contacto con los ambientes culturales y los círculos ilustrados madrileños más avanzados. Es en estos encuentros, en los que el teatro y los modelos clasicistas constituyen temas de debate privilegiados, animando las veladas de los contertulios que frecuentan la fonda de San Sebastián, que el autor napolitano fue madurando y delimitando los ejes de su pensamiento y al mismo tiempo afirmando sus gustos y preferencias literarias. Su inserción en el afamado cenáculo madrileño, constituyeron al mismo tiempo una valiosa ocasión para ampliar sus conocimientos sobre la cultura española, en particular sobre el teatro peninsular, al tiempo que le procuró nuevas e importantes relaciones, tanto sociales como culturales.

Los dos comediógrafos madrileños se erigen en doctos interlocutores de Napoli Signorelli, quien si en un primer momento se valió de los consejos y las sugerencias del autor de La petimetra, después de su desaparición prematura, comenzó a dirigirse de modo recurrente al joven Leandro para calibrar sus juicios y sus impresiones sobre el drama de la península, áureo y del dieciochos. Como hemos puesto de realce en otra ocasión, la correspondencia que el napolitano intercambió con el dramaturgo madrileño, además de confirmar esta importante relación de amistad que apoya en la mutua estima, reflejaba el consolidado vínculo de estrecha colaboración que los unió, basado en recíprocas solicitaciones de informaciones, de consejos y sugerencias y que apoyaba en una similar percepción del hecho teatral, especialmente de la comedia, y en una misma búsqueda estética (Quinziano 2002: 208).

Cabe recordar, sin embargo, que Napoli Signorelli, más que dramaturgo de cierto valor, fue sobre todo un atento estudioso de los escenarios europeos e inestimable crítico teatral, además de afirmarse como apreciable traductor de piezas dramáticas, griegas, francesas y españolas. De esta doble actividad de crítico dramático y traductor de textos españoles dan cuenta sobre todo tanto las amplias páginas que le dedicó al drama hispánico en su obra de

\footnotetext{
${ }^{5}$ Con el propósito de revisar y ampliar su primera edición de la Historia y crítica de los teatros, el napolitano recurre a la ayuda y a los consejos del amigo madrileño. "Don Leandro siguió por la parte más moderna lo que su padre había hecho por la antigua, favoreciendo a Napoli Signorelli en particular por la parte española y, sobre todo, en lo referente al penúltimo tomo, el noveno, de la última edición, que atañe a la segunda mitad del siglo XVIII e inicio del XIX" (Mariutti 1960: 774) Siendo el crítico napolitano un ferviente partidario del drama clasicista, sus juicios de valor no podían ser de ninguna manera imparciales; ellos se adaptan perfectamente a sus gustos y a sus preferencias estéticas, que por lo que respecta a la producción dramática española, se dirigen hacia el modelo consagrado por los partidarios del clasicismo dieciochesco, de modo especial Luzán y los dos Moratines.
} 
mayor alcance, la Storia critica de' teatri, como sus apreciables traducciones de las comedias de Leandro Moratín efectuadas durante el decenio 1795-1805.

Leandro Moratín, buen conocedor del drama italiano del dieciocho, del que admiraba de modo especial las comedias de Goldoni, traduce algunos pasajes de la Tirannia domestica, ovvero Rachele de su amigo Napoli Signorelli, sin olvidar que en aquellos mismo años volcaba también al español a Shakespeare (Hamlet) y dos piezas - El médico a palos y La escuela de los maridos- de Molière, uno de sus autores más admirados, todas ellas versiones, en opinión de Lafarga, "muy meritorias, que alternan con su producción original" (1992: 83).

Del mismo modo, Napoli Signorelli se ejercitó en la traducción de obras españolas, con el propósito de cultivar y difundir en Italia las virtudes de las letras españolas. Si el véneto Conti, en palabras de Fabbri "traductor culto y sensible" (1992: 151), vuelca al italiano la primera égloga garcilasiana (Madrid: 1771) y numerosas composiciones líricas del período áureo en su notable Scelta di poesie castigliane del secolo XVI (Padua: 1819), el hispanista napolitano traduce las cuatro primeras comedias moratinianas, o sea todas menos la última del madrileño, El sí de las niñas, la más lograda y mayormente celebrada de su breve, pero valiosa, producción dramática.

En tal sentido, no sería forzado aseverar que tanto las traducciones de las versiones italianas de las comedias realizadas por Napoli Signorelli como los amplios apartados por éste dedicados al teatro español en su Storia critica de' teatri antichi e moderni, muy probablemente no habrían visto la luz sin los insistentes estímulos y las recurrentes incitaciones de Nicolás Moratín y, de modo más evidente aún, sin la estimulante experiencia que para el crítico italiano representó su participación en los encuentros literarios que tenían lugar en la célebre tertulia durante sus años en Madrid (Quinziano 2001: 261). Leandro Moratín recuerda que gracias al estímulo de su padre, Conti había acometido su versión italiana de la égloga garcilasiana, mientras del mismo modo cruciales habían sido asimismo los consejos que el autor de La Petimetra le había sugerido a Napoli Signorelli en lo referente al teatro español, instruyéndole sobre los méritos y defectos de la escena nacional e influyendo sin duda en mucho de los juicios que el hispanista volcó en su Storia critica de' teatri. En esta línea, Rossi ha observado que "Moratín ha contribuido, por medio de [Napoli Signorelli...] a incrementar la atención extranjera por el teatro de su país" (1974: 133).

La amplia lista de traducciones, adaptaciones y refundiciones de composiciones líricas y textos teatrales, ya sean españoles o italianos, que confirma el ejercicio de la traducción como vehículo privilegiado de difusión y asimilación cultural, de ningún modo se halla desvinculada de esta estimulante fase de contactos, de debate cultural y aportaciones recíprocas que determinó la configuración de una original cultura hispanoitaliana en aquellos decenios a caballo entre dos siglos.

La crítica ha subrayado esta prodigiosa fecundidad por lo que concierne a la actividad traductora a lo largo del $\mathrm{XVIII}^{6}$, sobre todo en el campo teatral, pudiéndose reconocer tanto la existencia de traductores de oficio, "como el conocido Bernardo $\mathrm{M}^{\mathrm{a}}$ de Calzada, a quien llamó Moratín 'eterno traductor de mis pecados' “ (Lafarga, en Gies -Russell Sebold

\footnotetext{
${ }^{6}$ Sobre la actividad traductora en el XVIII existe en la actualidad una bibliografía abundante; entre las aportaciones más importantes se remite al estudio de I. Urzainqui (1991: 623-38) y los dos volúmenes colectivos editados por el profesor F. Lafarga (1997 y 1999).
} 
1992:80) ${ }^{7}$, como la de un número nada desdeñable de autores-traductores-adaptadores, figuras emergentes en el variado panorama que ofrece el drama dieciochesco español. Tanto Signorelli como Leandro Moratín prestaron especial a la actividad traductora en campo dramático. No se olvide que el comediógrafo español siempre demostró interés hacia dicha actividad, atendiendo en especial a su insustituible instrumento de difusión cultural y de recepción de obras teatrales, como corroboran las importantes anotaciones que acompañan su Viaje italiano y los apuntes que nos legó sobre algunas comedias españolas traducidas a la lengua italiana (ms. 12962/74), y de los cuales se ocupó Belén Tejerina (1983-84: 364$80)$.

La praxis traductora, como ejercicio intelectual habitual, constituyó un aspecto relevante en las reuniones que animaban el célebre cenáculo literario. La preocupación por la labor traductora hace referencia a una parcela temática de relieve en los debates que allí tuvieron lugar (Caso González 1992). En Signorelli, como en varios de sus compatriotas que asistían a las veladas de la fonda de San Sebastián, resulta evidente el interés y la preocupación constante hacia las cuestiones atinentes a la lengua y la importancia de la actividad traductora, atendiendo a las peculiaridades de cada idioma y a las costumbres de cada nación, temas recurrentes en los debates dieciochescos. Por tanto, en cierto sentido, esta intensa y laboriosa actividad fue también el resultado de aquel clima de profunda amistad y de abierto debate cultural que había imperado en la inquietante tertulia madrileña.

\section{Napoli Signorelli, traductor del teatro moratiniano}

Existe unanimididad entre los críticos acerca de las novedades del que es portador el modelo dramático moratiniano, siendo uno de sus mayores méritos el haber desbrozado el camino hacia la definitiva consolidación de la comedia realista burguesa, centrada en el retrato de arquetipos y ambientes representativos de "una clase media, inestable sin duda, pero ansiosa y curiosa por su propia inestabilidad" (Derozier 1980: 74), y escogidos por su capacidad de dotar a la pieza dramática de mayores indicios de verosimilitud La historia literaria española ha venido destacando que la gran aportación del dramaturgo madrileño radica en su capacidad de retratar con veracidad personajes y situaciones de la vida cotidiana y en captar con inimitable pericia ambientes y relaciones sociales en los escenarios, acompañándolos con una asombrosa modernización del lenguaje adoptado, lo que confiere mayor realismo a la representación teatral'. Y si es verdad que a partir de ello los ambientes y los personajes que pueblan la escena del célebre dramaturgo son más bien reducidos y limitados, éstos de todos modos, como compensación, se hallan retratados con veracidad y pericia dramática. En efecto, si las comedias de Iriarte y, de modo parcial las de

\footnotetext{
${ }^{7}$ Un adecuado y actualizado estado de la cuestión sobre la traducción en la España de finales del Setecientos y primeros decenios del XIX, con una amplia bibliografía adjunta, puede consultare en F. Lafarga (1999: 11-31).

${ }^{8}$ Sobre la primacía de las clases medias urbanas en el drama moratiniano, tanto en su condición de protagonistas destacados como de privilegiados receptores de dicho modelo teatral, véase el espléndido estudio de Maravall (1988: 163-92).

${ }^{9}$ No es este el lugar para extendernos sobre los componentes y las ideas-fuerza sobre los que apoyó el modelo teatral de Moratín. Sobre ello existe una amplísima bibliografía de la que, por obvias razones, es imposible dar cuenta en estas páginas. Las aportaciones más relevantes pueden consultarse en el repertorio bibliográfico de L. Brunori (1980: 269-96) y en la indispensable bibliografía de Aguilar Piñal (1984, III: 341-402). Asimismo puede recabarse un adecuado repertorio de textos críticos dedicados al drama moratiniano en la sección bibliográfica de la citada edición de Pérez Magallón (1994: 327-48), menos exhaustiva que las anteriores, pero bastante actualizada.
} 
Trigueros, despiertan el interés y la entusiasta aprobación del crítico partenopeo, indiscutible se nos revela su adhesión y solidaridad con el modelo dramático de Moratín. Sin desmerecer las apreciables aportaciones del teatro iriartiano hacia la definición de la comedia burguesa, se ha puesto de realce de modo atinado que fue Leandro Moratín, sin duda el más prestigioso dramaturgo del setecientos, "quien supo dar con la fórmula dramática adecuada a esos temas de actualidad, con la creación de personajes más complejos que los de Iriarte, al menos en sus comedias más logradas" (Andioc 1982: 262).

Signorelli dejó constancia en numerosas ocasiones de su admiración hacia el teatro de su amigo entrañable, explicitando su aprecio hacia una fórmula en la que los principios horacianos de utilidad y deleite se conjugan plenamente, compartiendo al mismo tiempo los propósitos instructivos y de reforma moral de los que dicho modelo dramático se erige en portavoz. Aunque en esta relación no faltaron observaciones y objeciones críticas, como las que Napoli Signorelli le transmitió al comediógrafo español, siempre con espíritu amistoso, a raíz de la lectura de $E l$ viejo y la niña, el hispanista italiano acogió favorablemente las piezas del autor madrileño (las temáticas, los perfiles de los personajes y el valor didáctico y moral que las mismas exhiben), siendo muy alta la estimación que demostró hacia su modelo teatral.

Numerosas fueron las coincidencias y afinidades estéticas que acomunaron a ambos dramaturgos; semejanzas que pueden ser corroboradas a partir de una lectura de algunas de las más significativas obras de índole teórica que nos han legado ambos literatos, especialmente los Orígenes del Teatro Español (Obras: 147-77) y las Advertencias (Obras: 335-6, 356-7, 373-4 y 392) y el Discurso preliminar que el autor de El sí de las niñas puso al frente de sus Comedias (Obras: 307-325), la ya aludida Storia critica de' teatri (1813, IX: 169-87) y los Elementi di poesia drammatica (1801: 81-87) del autor napolitano. De un primer análisis comparativo de estas obras aflora una común valoración del teatro, y en particular de la comedia, como instrumento educativo insustituible de reforma moral y social, orientado a poner en evidencia los vicios y los defectos de los hombres, con el propósito de desterrarlos y valorizar la virtud. Se ha observado con razón, que para los defensores del neoclasicismo, como es el caso de ambos dramaturgos, reformar el teatro significa principalmente "cambiar las costumbres y la mentalidad de la nación" (Sánchez Blanco 2002: 151) y "advertir sobre vicios y errores, (...) distribuir luces y procurar preparar a individuos de diferentes niveles sociales a ser útiles a la sociedad" (Maravall 1988:12). Tan sólo a modo de ejemplo bastará aquí recordar la similitud en la apreciación de los componentes y del rol asignado por ambos a la comedia neoclásica. El madrileño opina que "la comedia pinta a los hombres como son, imita las costumbres nacionales y existentes, los vicios y errores comunes, los incidentes de la vida doméstica, y de estos acaecimientos, de estos individuos y de estos privados intereses forma una fábula verosímil, instructiva y agradable (...)" (Obras: 320). En esta misma línea el erudito italiano concibe al género cómico como "imitazione rappresentativa piacevole, fatta con metro o con prosa (...), condotta con ogni verosimiglianza per rendere il vizio spregevole coll'aiuto del ridicolo" (Elementi:82).

En su Discurso Preliminar el madrileño indica que la comedia se halla orientada a proponer una imitación verosímil de la realidad, y a tal propósito debe escoger una fábula "verisímil, instructiva y agradable" (Obras: 320), definiendo al género cómico como 
Imitación en diálogo (escrito en prosa o verso) de un suceso ocurrido en un lugar y en pocas horas entre personas particulares, por medio del cual, y de la oportuna expresión de afectos y caracteres, resultan puestos en ridículo los vicios y errores comunes en la sociedad y recomendadas por consiguiente la verdad y la virtud" (Discurso Preliminar, en Obras: 320).

El retrato de las costumbres nacionales, la obediencia de las unidades clásicas en base a los preceptos sancionados por Boileau (Obras: 321; Elementi: 86), el afán de reforma teatral y de la sociedad dieciochesca en general, la exaltación de la virtud y su innegable finalidad didáctica, social y moral definen los componentes más significativos del modelo dramático moratiniano, orientado a la definición del teatro realista burgués, ampliamente compartidos por Signorelli ${ }^{10}$.

El literato partenopeo comprendió perfectamente los contenidos encaminados a la reforma de la sociedad que modelaban el teatro de Moratín, por el concebido como el mayor exponente de la comedia realista de carácter burguesa, y los propósitos didácticos que lo inspiraban. No asombra, pues, de ningún modo que Signorelli le dedique amplias páginas en su Storia critica dei teatri (Storia, IX: 169-187), del que de modo incuestionable emerge la gran estima hacia el célebre autor. Para el hispanista napolitano, el joven dramaturgo había heredado de su padre Nicolás "l'indole poetica, l'eleganza e la grazia dello stile, la dolcezza del verseggiare e la purezza del linguaggio" (Storia, IX: 169). En una carta redactada en abril de 1803, con ocasión de la publicación ese mismo año de El barón, el autor italiano se congratulaba con su amigo, poniendo de realce las virtudes allí presentes,a saber :

"La sencillez de su fábula, la pintura á lo vivo de los caracteres que representan las costumbres nacionales, la propiedad del diálogo, la elocución pura, urbana y graciosa sin bufonadas, y conveniente a la buena comedia, además de la moral instrucción que se desea en las comedias (...)" (en Mininni 1914: 437).

Algunos años más tarde, el autor napolitano corroboraba su favorable impresión con palabras muy similares, evidenciando que "la favola semplice e verosimile, i caratteri tratti addirittura dalla natura, i costumi nazionali vivacemente dipinti, un dialogo naturale (...) vezzi comici senza esagerazione istrionica, ottima morale (...) sono i pregi che gli imparziali non possono negare (...)" (Storia, IX: 187). En esta total comunidad de intereses, pues, era natural que el hispanista napolitano no sólo reivindicase la producción teatral de su amigo, sino que se empeñase en difundir su obra allende los Pirineos, de modo especial en los escenarios de Italia.

Como se ha apuntado, del popular dramaturgo español Signorelli tradujo al italiano sus primeras cuatro piezas -La commedia nuova, Il Vecchio e la giovane, Il Barone y La Bacchettona-, o sea todas menos la mayormente lograda El sí de las niñas, dejando así constancia de la plena adhesión que el erudito partenopeo guardó hacia los principios que regían la visión dramática del madrileño y con la cual el escritor italiano se solidarizó de modo explícito. Es el mismo italiano, quien en una carta de principios de octubre de 1806,

\footnotetext{
${ }^{10}$ El autor madrileño privilegió las comedias de carácter, auspiciadas también por el comediógrafo partenopeo por sobre las comedias de enredo (Elementi: 89-90), en las que el diálogo se impone como uno de sus marcas distintivas y centradas en el carácter que revelan los personajes, cuyos comportamientos, como puede leerse en un períodico florentino en su número de diciembre de 1780, al mostrarnos "con orrore tutti quei vizi, tutti quei difetti che corrompono gli uomini", se hallaban orientados a "corregere lo spettatore colla pittura sempre viva e contrastata dagli originali”, Giornale Enciclopedico della letteratura italiana e oltremontana, Florencia, número 6, pp. 56-7.
} 
le explica al madrileño las razones de dicha ausencia, señalándole que una obligada y veloz lectura y la imposibilidad de poder disponer por más tiempo del texto le habían impedido emprender la traducción de su última -y más lograda- pieza dramática ${ }^{11}$. La traducción de la famosa comedia moratiniana sería llevada a cabo algunos años más tarde, en 1830, apareciendo ese mismo año incluso dos versiones italianas distintas, una en Marsella y otra en Milán ${ }^{12}$. Al compararlas con las emprendidas por nuestro autor, Sánchez de Rivero advierte que las del hispanista napolitano "son algo vivo, lo que se refleja también en las eventuales notas, en las noticias histórico-críticas del mismo traductor brotadas no tan sólo de la amistad con el autor, sino más del interés del estudiosos de teatro que gusta de dar a conocer unas obras que son el testimonio de una conquista literaria y representan algo nuevo en la historia del teatro español" (1960: 794).

Los manuscritos de las traducciones de Signorelli se hallaban depositados, al menos hasta mediados del siglo pasado, en la Accademia Pontaniana de Nápoles, antes Accademia di Scienze e Lettere, de la que nuestro autor había ocupado la función de Secretario durante varios años. Allí pudo consultarlos Mininni a principios del siglo pasado y, al parecer, a finales de los años 50' también la estudiosa Angela Mariutti. Sin embargo, dichos documentos hoy lamentablemente parecen haberse extraviados, puesto que ya no es posible localizarlos ni en la mencionada Academia, donde se hallaban depositados, ni en la bien abastecida Biblioteca Nazionale de la ciudad partenopea ${ }^{13}$. A excepción de La commedia nuova, incluida en su cuarto Opuscolo que vio la luz en 1795 (Opuscoli, IV: 183), es de suponer que las restantes piezas de Moratín fueron traducidas durante su estancia en la ciudad de Milán, mientras el italiano se desempeñaba como profesor en el Gimnasio de Brera, entre 1801 y $1804^{14}$. Estas tres versiones, Il Vecchio e la giovane, Il Barone y La Bacchettona, fueron publicadas poco tiempo después, entre 1805 y 1806, para la prestigiosa

\footnotetext{
${ }^{11}$ Napoli Signorelli le escribe al comediógrafo español: "Es verdad que D. Simón Rodríguez me pasó su última comedia El sí de las niñas, pero con el que la leyese y se la volviese sin tardar; así lo hice. Yo la habría traducido quedando en mi poder, como lo he hecho de su Barón, de la Mojigata y del Viejo y la Niña. Estas tres las traduje sin alteraciones, como en La Comedia nueva me lo había permitido. El Barón y El viejo y la Niña están impresas El año teatral de Venecia, ni tengo de ellas ejemplar alguno. La Mojigata, que tuve a bien llamar La Bacchettona, no se admitió por escrúpulos del Govierno Austríaco de entonces [...] Lo cierto es que las cuatro comedias de V. que yo conozco las he traducido. Pero hay otra, que yo no conozco?" (en Mininni 1914: 439). Sorprende en cambio el silencio sobre la última pieza moratiniana en la última edición de laStoria critica, donde el italiano alude en 1813 a El barón una vez más como la última comedia del amigo de que él tenía noticias (Storia, IX: 185).

12 En 1830 salen a la luz dos versiones de la popular pieza: una más fiel al texto español, editada por L. Monteggia, Il si delle fanciulle. Commedia in tre atti in prose di L. F . di Moratín. Versione dallo spagnolo di Luigi Monteggia, colaborador del periódico barcelonés El Europeo (Marsella, s.e., 1830) y una adaptación italiana mucho más libre realizada por D. E. Govean, Il sì delle ragazze. Commedia in tre atti tradotta dall'originale spagnolo (Milán, Visaj, 1830). Más tarde, a prinicipios de los años cuarenta se editó una tercera versión italiano, aún más libre de las precedentes, publicada también en Milán: Sì col labbro e non col cuore (Milán, 1841), traducida por Carlo Varese. Véase a este respecto A. Mariutti de Sánchez de Rivero (1960: 793-4).

${ }^{13}$ Belén Tejerina, al abordar el problema de la desaparición de los cuatro volúmenes de manuscritos del hispanista napolitano al que se refiere Mininni (1914: 521-522), apunta que "oggi a Napoli, sia alla Biblioteca dell'Accademia Pontaniana sia alla Biblioteca Nazionale si ignora dove siano finiti questi quattro grandi volumi; sembra che essi siano andati bruciati durante la guerra del 1940-45, ma non esiste alcun documento che dia ragione della perdita" (1996: 108). A continuación la estudiosa se pregunta entonces con razón: “Com'è possibile che A. Mariutti li abbia consultati intorno al 1959-60 se andarono bruciati nel 1945? Li aveva forse consultati vent'anni prima, oppure, sebbene non lo dica esplicitamente, la studiosa cita di seconda mano il libro di Mininni?", explicación -esta última- por la que Tejerina parece inclinarse; véaseCriteri di edizione e traduzione, en Tejerina ed. (1996: 108-9).
} 
colección Anno Teatrale ${ }^{15}$, la cual proseguía la valiosa labor de difusión teatral que por decenios había llevado a cabo la otrora acreditada colección veneciana Teatro Moderno Applaudito del editor Antonio Stella.

Las versiones llevadas a cabo por el autor napolitano se inscriben en esa larga tradición de obras traducidas, adaptadas, arregladas y refundidas que habían modelado las relaciones dramáticas entre ambas penínsulas hespéricas a lo largo del XVI y XVII, y que habían consentido la difusión y representación de numerosas obras teatrales españolas en los escenarios italianos (Lope, Tirso, Calderón, Moreto y Ruiz de Alarcón, de modo especial). Signorelli, experto conocedor de la lengua española, traduce las comedias del autor madrileño con pericia lingüística y consistencia dramática, manipulando en algunos casos con cierta libertad los elementos y procedimientos teatrales con el propósito de adaptarlos a la escena italiana y a las procupaciones y gustos del público de la península ${ }^{16}$.

Del mismo modo, sumamente intensa fue la labor de traducción y adaptación al español de piezas italianas llevada a cabo por literatos y eruditos a lo largo del setecientos, y que posibilitaron que el público español conociese y admirase los melodramas de Metastasio, las comedias de Goldoni y, algunos años más tarde, las tragedias del piemontés Alfieri. A este respecto, Lafarga opina que "el siglo XVIII -sobre todo en su segunda mitad-, así como el primer tercio del siglo XIX, son etapas de efervescencia de la actividad traductora. La multiplicación de las relaciones culturales, la cada vez mayor facilidad (...) de acceso a las lenguas extranjeras, con el consiguiente aumento en número y en calidad de las herramientas de aprendizaje y uso, como gramáticas y diccionarios, el ansia misma de

\footnotetext{
${ }^{14}$ Los años en que Signorelli residió en Milán, entre 1801 y 1804 , ejerciendo como director y profesor de Declamazione en la Escuela de la Accademia del Teatro pattriotico y de Poesia rappresentativa en la escuela pública de Brera, fueron muy probablemente los más fecundos de su fase más madura. Sobre la estancia del napolitano en la ciudad lombarda, véase Mininni (1914: 171-188). Lamentablemente las alusiones del biógrafo a las comedias de Moratín traducidas en dicho período son más bien escasas y sus apreciaciones no siempre atinadas, cuando no superficiales y forzadas (1914: 185 y 187).

${ }^{15}$ L. F. de Moratín, Il vecchio e la giovane, trad. di P. N. Signorelli, A. Rosa, Venecia, 1805, Anno Teatrale, II, Tomo III (agosto) (El viejo y la niña, B. Cano, Madrid, 1790; Il Barone, trad. di P. N. Signorelli, A. Rosa, Venecia, 1806, Anno teatrale, III, Tomo II (febrero) (El barón, Villalpando, Madrid, 1803); La bacchettona, trad. di P. N. Signorelli, A. Rosa, Venecia, 1806, Anno Teatrale III, Tomo VIII (agosto) (la mojigata, Villalpando, Madrid, 1804). La prestigiosa colección teatral italiana acogió numerosas piezas del teatro europeo; éstas para su publicación, entre otras normas establecidas, como anuncia en su "Avviso agli autori e traduttori", debían presentar "uno scopo di sana morale" y respetar "almeno le principali regole della drammatica"; en Anno Teatrale, continuazione di Teatro Moderno Applaudito, ossia Raccolta Annuale año II, Tomo I, Venecia, A. Rosa, 1805, XXXV-XXXVI. De todas ellas existe sólo una ed. moderna de Il Vecchio e la giovane, editada por Belén Tejerina, con un interesante estudio introductorio (1996: 7-77) y un esmerado aparato crítico filológico.

${ }^{16}$ El crítico napolitano, no se olvide, no sólo se cimentó en la traducción de comedias de obras españolas, sino que adaptó y volcó al italiano tanto tragedias griegas como piezas de los clásicos franceses, aunando algunas de ellas en una apreciable perspectiva comparativa: Delle migliori tragedie greche e francesi, Milán: Stamperia e Fonderia al Genio, 1804-1805, 3 vols. En dicho esfuerzo destaca el análisis y las traducciones delHipólito de Eurípides y la Fedra de Racine y el análisis y la traducción de la Ifigenia in Aulide de Eurípides con la homónima del célebre dramaturgo francés. Cfr. al respecto Mininni (1914: 181-5). Por los mismos años que salían a la luz sus traducciones de las comedias moratinianas, Signorelli publicaba también para la colección teatralde Anno Teatrale, las versiones italianas de tres dramas franceses: la tragedia de Voltaire L'orfano della Cina (1804) y las comedias L'ingresso del mondo (1804) e I perturbatori delle famiglie (1805), ambas de Picard, sin olvidar la versión italiana de la famosa Misantropia e Pentimento de Kotzebue, redactada por el literato napolitano entre 1800 y 1801 durante su breve exilio parisino, donde, junto a otros patriotas napolitanos, el hispanista se había refugiado a raíz de la caída de la efímera Repúbblica partenopea.
} 
ampliar los conocimientos y el saber, tan propia del espíritu ilustrado, todo ello favorecía el auge de la traducción" (1999: 11).

Ahora bien, si las traducciones de las piezas de Moratín lograron publicarse en Italia poco tiempo después que saliesen a la luz y casi al mismo tiempo que se representaban en los escenarios de España, más bien limitada fue la difusión que las mismas alcanzaron en la Italia del dieciocho. Conviene recordar que, según los datos de que se dispone, de las cuatro, sólo Il vecchio e la giovane, "recibida con aplauso público" según apuntaba el mismo Moratín (Obras: 336), y La bacchetona, muy probablemente la más fiel al original de todas, lograron subir por aquellos años en los escenarios italianos, representándose esta última en el Teatro Filodrammmatico de Milán a finales de 1800 e inicios de $1801^{17}$, o sea años antes de que saliese a la luz la versión italiana de Napoli Signorelli (1806), aunque es probable que la misma ya estuviese redactada para ese período, sirviendo de base para la representación milanesa.

La traducción favoreció sin duda un más adecuado conocimiento y al mismo tiempo una mayor difusión de literatos y textos, acercando autores y obras de una cultura a otra y determinando o afianzando nuevos gustos y preferencias estéticas en la cultura recceptora.. Baste citar, a modo de ejemplo, la importancia asignada a la libre traducción al español de las Riflessioni sopra il buon gusto de Muratori, llevada a cabo en 1782 por el erudito alicantino Sempere y Guarinos, y que constituyó un notable punto de referencia para los defensores de la nueva estética neoclásica en las letras españolas, si bien muchas de las sugerencias del preceptista italiano ya habían sido introducidas indirectamente algunas décadas antes a través de la Poética luzaniana. Asimismo no debe olvidarse que una parte considerable de las obras publicadas por los desterrados en Italia fueron escritas, no en español, sino en lengua italiana, como nos revelan los primeros tomos de la Storia critica della Spagna de José Masdeu, el célebre tratado histórico sobre el teatro musical de Esteban de Arteaga, Le rivoluzioni del teatro musicale italiano dalla sua origine fino al presente (1783-88), y la enciclopédica historia de la cultura del padre Andrés, Dell'origine, de' pogressi e stato attuale d'ogni letteratura (1782-1789). Del mismo modo las tragedias de los jesuitas Colomés, García y Lasalla, como la mayoría de las obras editadas por la diáspora jesuita afincada en Italia y en demostración de la alta estimación que de la lengua de Dante guardaron los emigrados, fueron redactadas en un prolijo italiano, para luego, sucesivamente, ser volcadas muchas de ellas al español.

Al aproximarnos y juzgar la labor de traducción conviene tener siempre presente las fronteras, por lo demás ampliamente difusas, que en aquellos años, existían entre el trabajo del traductor y el que realizaba en cambio el adaptador. En efecto, la concepción que caracterizaba la labor traductora en la segunda mitad del XVIII concedía mayor libertad al

\footnotetext{
${ }^{17}$ G. Martinazzi señala que la pieza española se representó el 31 de diciembre de 1800 , mientras que otras dos obras teatrales traducidas por el napolitano fueron representadas en el mismo coliseo de Milán en los primeros años del siglo XIX (Abbé de l'Épée: 11 de marzo de 1801 y Misantropia e pentimento: 11 de marzo de 1803); Accademia de' filodrammatici di Milano (Milán, Pirola, 1879: 115-7). Mininni, recordando los obstáculos que la pieza había tenido que enfrentar antes de que se publicara en España. Basándose muy probablemente en las palabras del mismo Signorelli, quien en una carta al dramaturgo español, le señalaba que, si bien había traducido al italiano La mojigata, la misma "no se quiso admitir por escrúpulos del Gobierno Austríaco de entonces (...) " (1914: 439). Mininni sostuvo que la traducción italiana no había sido publicada, asegurando de modo equivocado que la versión del dramaturgo napolitano permanecía inédita; (1914: 185 y 524-5). Cfr. a este respecto también Mariutti de Sánchez Rivero, quien anota la equivocación en que cae Mininni, mientras que es más bien cauta en cuanto a la representación de la pieza de Moratín en los escenarios italianos (1960: 790-1).
} 
traductor, cuya labor en verdad se colocaba más bien a mitad camino entre la traducción propiamente dicha, tal como hoy la concebimos, y la libre adaptación ${ }^{18}$. En aquellos mismos años José Cadalso advertía en sus Cartas marruecas (1789) sobre las numerosas dificultades a las que se exponía el trabajo del traductor en los últimos decenios de la centuria. El poeta gaditano no puede dejar de observar que como los traductores

"no saben su propia lengua, porque no se sirven tomar el trabajo de estudiarla, cuando se hallan con alguna hermosura en algún original francés, italiano o inglés, amontonan galicismos, italianismos y anglicismos, con lo cual $[\ldots] 1^{\circ}$, Defraudan el original de su verdadero mérito, pues no dan la verdadera idea de él en la traducción; $2^{\circ}$, Añaden al castellano mil frases impertinentes, $3^{\circ}$ Lisonjean al extranjero, haciéndole creer que la lengua española es subalterna a las otras (...)" (1990: 200-1).

Al sugerir los métodos para traducir al español, Cadalso aconsejaba en primer lugar una lectura atenta del original y una reflexión concienzuda sobre los pasajes que debían volcarse a la lengua castellana, reivindicando en dicha perspectiva su "familiaridad con los españoles del siglo XVI y algunos del XVII [quienes lo habían sacado...] de muchos apuros" (1990: 242). Además del poeta andaluz, numerosas fueron las voces que alertaron sobre lo que ellos consideraban los 'efectos perniciosos del lenguaje'. En este sentido cabe recordar en primer lugar al padre Feijoo, al que más tarde se asociaron Sarmiento, Forner y Capmany, quienes acusaron a los traductores, oficio aún no muy bien visto en el XVIII, de ser los mayores responsables de la corrupción que se había apoderado de la lengua. Al referirse a la tarea del traductor, plenamente consciente de la responsabilidad, del empeño y la seriedad que comportaba dicha labor, y como se desprende de las oportunas notas aclaratorias que ha dejado estampadas en la versión italiana de la Comedia nueva, Signorelli asevera que las traducciones deben ser efectuadas por "manos expertas, de lo contrario las mismas distorsionan los originales (...) o deforman el propio idioma, con las fórmulas extranjeras que introducen" (Opuscoli, II: 147).

Por lo que atañe a las cuatro traducciones de las comedias moratinianas que nos ha legado el autor de La Faustina, ellas confirman las cualidades del autor napolitano como hábil traductor, al tiempo que demuestran sus vastos conocimientos sobre el teatro hispánico del período, del que fue entusiasta estudioso y atento observador. Al respecto Cian ha opinado que el erudito napolitano "fu lo spagnolista più insigne, e fu tra gli italiani e non tra gli italiani soltanto, il conoscitore più originale e il più sicuro (...) ilustratore della drammatica spagnola" (1896: 208). Sin olvidar algunas libertades artísticas que el italiano en ciertas ocasiones se concede (añadidos, sustituciones, etc.), puede aseverarse sin temor a equivocarnos que las versiones de Signorelli constituyen traducciones bien logradas y en términos generales son respetuosas del original español ${ }^{19}$.

El mismo dramaturgo napolitano precisa que ha emprendido las traducciones de las piezas del comediógrafo español sin operar alteraciones relevantes ${ }^{20}$, interviniendo sobre los textos dramáticos para aportar, según sus propias palabras, sólo "pequeños cambios (...) de poca importancia" $(\mathrm{CNi}, 53)$, y por tanto respetando las finalidades, las trazas caracteriales

\footnotetext{
${ }^{18}$ Sobre el concepto y la teoría de la traducción en Italia en la fase a caballo entre Setecientos y Ochocientos, se remite al esclarecedor estudio de Emilio Mattioli (2001: 88-101).

${ }^{19}$ Sobre las traducciones de Signorelli, se remite a Mariutti de Sánchez Rivero (1960: 775-794), Caldera (1980: 149-160) y nuestro estudio (Quinziano 2001: 267-272).

${ }^{20}$ Carta de P. Napoli Signorelli a L. F. de Moratín (Nápoles, 3 de octubre de 1806), en Mininni (1914: 439).
} 
y las situaciones que exhibe el original. Sin embargo, lo cierto es que no fueron pocas las intervenciones y las modificaciones llevadas a cabo por el crítico partenopeo, encaminadas fundamentalmente a respetar el gusto italiano, acercando la obra al público de la península, consciente de que, como nos recuerda Tejerina, "seguir el gusto y las costumbres de un país es en el siglo XVIII una regla de belleza" (1995: 177). En efecto, no son pocos los cambios operados por el traductor italiano en su labor por acercar y adaptar los textos del autor español a los escenarios italianos; modificaciones que por lo general abarcan el plano del léxico, pero que en algunos casos, como en el desenlace de Il vecchio e la giovane, logran incidir más radicalmente sobre los contenidos y el mensaje del que son portadoras las piezas del autor madrileño. En apretada síntesis, y a grandes rasgos, además de las citadas modificaciones en el plano del léxico, entre los cambios operados por el italiano pueden señalarse la sustitución de nombres, lugares y referencias espaciales, la elección de la prosa en lugar del verso (Il vecchio e la giovane, Il barone y La bacchettona), y la variación en las didascalías y acotaciones (diversa disposición, sustituciones, añadidos y supresiones).

Signorelli se solidariza con los temas y exalta el estilo que exhiben las obras de su amigo madrileño, al tiempo que evoca los no pocos obstáculos que el autor madrileño había tenido que sortear con la censura, con las autoridades y los mismos actores de las compañías para llevar sus obras a las tablas. El crítico napolitano, poseedor de un perfecto conocimiento de la lengua española, logra volcar de modo eficaz las expresiones idiomáticas y coloquiales de los que hacen gala la prosa moratiniana, atendiendo al mismo tiempo a los diversos matices semánticos y léxicos que en ella abundan, como expresión de la naturalidad y sencillez que se proponen alcanzar los partidarios de la nueva estética. Asombra el esfuerzo y la voluntad del hispanista por precisar constantemente vocablos, significados y valores semánticos, sin olvidar además las acotaciones referidas a los aspectos vinculados a la pronunciación y a los registros prosódicos del español.

Del mismo modo destacan las útiles y oportunas aclaraciones referidas a costumbres y patrones socioculturales (unidades monetarias, referencias topográficas, vestimentas, formas líricas privativas de la tradición hispanica, etc.), que promueven un mayor acercamiento de la obra al público italiano, facilitando una más rápida asimilación de los contenidos y de los valores de referencia de la que la misma es portadora. Numerosas son, en efecto, las anotaciones y las aclaraciones semánticas, léxicas y fonéticas que afloran en estas traducciones $^{21}$, confirmando el interés y la constante preocupación del dramaturgo italiano por precisar vocablos y conceptos. En otras ocasiones, como recuerda Mariutti (1960: 793), cuando el traductor napolitano no encuentra el vocablo italiano correspondiente o más adecuado, opta por dejar el término o la expresión en español, explicando luego en nota el criterio y la elección adoptados, como es posible leer en una de las pocas notas aclaratorias que añadió en Il barone, cuando explica que Veneranda duenna "si pronunzia duenna. Ciò

\footnotetext{
${ }^{21}$ Se ofrecen a continuación algunos breves ejemplos de esta conciencia lingüística que parece guiar a nuestro autor y que se expresa en acotaciones de pronunciación, en aclaraciones de tipo léxico y explicaciones de temas y formas literarias representativas de la cultura española: Illescas: "si pronuncia Igliescas" (Il Barone, 4); bagni di Trillo: si pronunzii Triglio" (Il Barone, 22 ); fracassò la sua carrozza e caddero le sue mule. "si aggiunge nell'originale la chispa y la vandolera, che significano la Santilla e la Bandita, nomi che i mulattieri sogliono dare alle mule" (Il Barone, 9). Diversas son también las acotaciones referidas a formas líricas o expresiones culturales hispánicas: sonadiglia: "canzonetta spagnola" (Il Barone, 4), mientras en varias ocasiones remite incluso a las consideraciones por él expuestas en su obra de crítica dramática: así, por ejemplo, luego de apuntar que la tonadilla es una "canzonetta nazionale", añade que "di essa e delle seghidiglie vedi laStoria [critica] de' Teatri" (CNi, 53, nota 2).
} 
si lascia in castigliano, perché non havvi un equivalente piacevole in italiano" (Il Barone: $55)$.

Muy oportunas se revelan por otro lado las referencias a la topografía madrileña ( $l l$ Barone y La commedia nuova), que el italiano conocía muy bien como es natural por haber vivido allí casi cuatro lustros y que explica en notas aparte. Respecto a la variedad de matices coloquiales y modismos familiares que exhiben los textos de Moratín, y a la fuerza expresiva del lenguaje que dicha variedad supone, como expresión de la naciente prosa moderna, puede aseverarse que el traductor napolitano logra asimilar eficazmente las variadas expresiones idiomáticas de las que el poeta madrileño hace alarde. En algunas de sus obras no es raro advertir por otro lado la presencia de determinadas expresiones castizas castellanas, muchas de ellas madrileñas, que confirman su amplio dominio del idioma, incluso en su registro coloquial. En esta perspectiva, Caldera ha puesto de realce con razón que el crítico napolitano, "buon conoscitore di espressioni idiomatiche nell'una e nell'altra lingua, è spesso in grado di decifrare con particolare vivacità -a volte superando il modellola frase che una traduzione letterale renderebbero insipida" (1980: 154).

Si las traducciones de Signorelli logran transmitir con pericia lingüística tanto los valores expresivos que se alojan en las fórmulas idiomáticas coloquiales y populares, como las múltiples acepciones semánticas que derivan de las variantes léxicas utilizadas por el madrileño, conviene precisar, sin embargo, que no son pocas las ocasiones en las que en las mismas logran filtrarse determinados hispanismos, muy probablemente, como anota acertadamente una vez más Caldera, "sfuggiti all'orecchio del traduttore che, senza rendersene conto, trasponeva omofoni da un sistema linguistico all'altro" (1980: 155). En efecto, debe precisarse que en más de una oportunidad el dramaturgo italiano traduce vocablos y conceptos incurriendo en ciertas imprecisiones lexicales, al incluir de modo inconsciente algunos hispanismos: así, por ejemplo, guardare = 'guardar', en el sentido italiano de 'mettere in disparte', o pretendere = 'pretender', en alusión a 'avere intenzioni' constituyen ejemplos evidentes y significativos de esta contaminatio lingüística ${ }^{22}$.

A modo de conclusión de este veloz excursus dedicado a las traducciones acometidas por Signorelli, es posible aseverar que dichas versiones, aunque en líneas generales respetuosas en cuanto a fiabilidad filológica, ostentan no pocos cambios, sustituciones y añadidos, en algunos casos -como se verá en las escenas conclusivas de La Commedia nuova- de no poca entidad, con el propósito de adaptarlas, según palabras de Masdeu, al "traje italiano" (cit. en Pérez Villamil 1980: 121), ya sea dotando algunas de ellas de mayor patetismo (Il vecchio e la giovane), ya sea acentuando determinados trazos caracteriales de los personajes, lo que otorga a las mismas una mayor carga de comicidad (La commedia nuova), o bien actuando simultáneamente en ambos sentidos, con la acentuación de rasgos patéticos y cómicos al mismo tiempo (Il Barone). Ello confirma una relativa autonomía por parte del traductor italiano respecto a los textos españoles, estableciendo con éstos una correspondencia más de orden estético, ideal y de fondo que literal.

Sin subestimar los cambios y los añadidos orientados a adecuar los textos moratinianos al gusto italiano, y las aludidas transposiciones lingüísticas, no hay dudas de que las

\footnotetext{
${ }^{22}$ A este respecto, Caldera (1980: 155-6) ofrece algunos interesantes y bien representativos ejemplos de dicha transposición lingüística: bodegas/botteghe (La bacchettona, I, 4); hace falta/fa mancanza (Il barone, II, 10); acudir/accudire (La bacchettona, III,2); es muy buena la especielè molto curiosa la specie (Il barone,I,4), no te enfades/non t'infadare (Il barone, II, 12).
} 
traducciones de Signorelli se revelan respetuosas y bastantes cercanas a los originales españoles. En lo que atañe al plano de la lengua, Napoli Signorelli confirma su gran dominio del español, en el que, como anota Caldera, se percibe un valorable esfuerzo por ajustar el texto a la lengua receptora, "inseguendo il vocabolo, o il sintagma, o la formula più tipicamente italiani o particolarmente efficaci" (1980: 153). Desde el punto de vista lingüístico las versiones italianas de las piezas de Moratín confirman la sensibilidad y la habilidad del traductor napolitano, quien demuestra seguridad y pericia en la elección de vocablos y de expresiones idiomáticas, transponiéndolos eficazmente a la lengua italiana, al tiempo que evidencian su óptimo conocimiento de la lengua española, que el erudito había logrado perfeccionar durante sus largos años en Madrid, en sus más diversos registros: cultos, coloquiales, familiares. En este valorable esfuerzo por adecuar a las letras italianas el drama moratiniano, resalta la capacidad del hispanista italiano por trasponer eficazmente los diversos registros y estilos que informan el léxico del comediógrafo español, ajustados todos ellos al carácter y al decoro de los personajes y atendiendo tanto a una adecuada asimilación de las variadas expresiones idiomáticas y coloquiales como a resaltar la riqueza semántica de los modismos familiares de los que hace gala la prosa moratiniana.

\section{LA COMMEDIA NUOVA (1795): POLÉMICA TEATRAL Y APROPIACIÓN TEXTUAL}

La comedia nueva fue la primera pieza moratiniana traducida por el erudito partenopeo, siendo incluida en el cuarto volumen de sus Opuscoli Vari que vio la luz en Nápoles en 1795 (Opuscoli, IV: 1-54) ${ }^{23}$. La publicación de la versión italiana coincidió con la presencia del autor español en Italia, quien, como es bien sabido, en aquellos años, entre fines de 1793 y 1796, recorría la península, visitando amigos, conociendo ciudades de arte y frecuentando los espectáculos teatrales, sobre los que nos ha dejado páginas memorables en su Viaje en Italia. En esta primera traducción, a diferencia de Il barone, en la que añade algunas breves escenas, respeta la disposición asignada por el autor español: dos actos de seis y nueve escenas respectivamente.

El escritor napolitano, consciente de los contenidos y de los propósitos de reforma que albergaba la pieza, se solidarizó con su finalidad didáctica y sus propósitos de reforma, por él plenamente compartidos. "Con muchísimo placer he leído su comedia- le escribe al madrileño en marzo de 1792- y veo que merece los aplausos con que la recibieron. (...). La pieza tiene sal y arte, pinta muy bien a lo vivo y lleva fina moral, (...) hace reír pero instruye", para concluir, luego de haber leído el manuscrito que el mismo literato español le había enviado, que el teatro español habría "de ganar en este espejo" (en Mininni 1914: 417). En términos muy similares se expresaría algunos años más tarde en su monumental historia teatral. En las páginas dedicadas al drama de Moratín, al referirse a La comedia nueva, opina que "la locuzione è propria e naturale, l'azione semplice condotta felicemente, lo scioglimento fa onore all'umanità ed in conseguenza all'autore" (Storia, 1813, IX: 184-5).

De las cuatro traducciones, es sin duda ésta la que reviste mayor interés por lo que atañe a la comprensión de la historia del teatro español y la perspectiva que el italiano traza

\footnotetext{
${ }^{23}$ Napoli Signorelli ofrece útiles noticias sobre esta traducción en el apartado dedicado al teatro moratiniano de su Storia de' teatri (Storia, IX: 185). Sobre la traducción de Signorelli véanse A. Mariutti de Sánchez Rivero (1960: 775-83), E. Caldera (1980) y nuestro estudio (Quinziano 2001: 272-87). Un ejemplar de la traducción de Signorelli se encuentra depositada en la Biblioteca Nazionale di Napoli, mientras otros ejemplares pueden ser consultados en la Biblioteca Sormani de Milán (M Vet 394) y en la Nazionale Braidense de la misma ciudad italiana (RR II 4). Se señala que se encuentra en preparación para su próxima publicación nuestra edición bilingüe -española e italiana - de la comedia de Moratín.
} 
sobre este aspecto relevante en el panorama cultural del dieciocho, así como para la recepción en Italia de las ideas teatrales del comediógrafo madrileño. En efecto, si la famosa pieza moratiniana se halla estrechamente vinculada a los debates y a las animadas polémicas que ocuparon los últimos decenios del siglo y que vio a los partidarios de la estética neoclásica librar una batalla por desterrar de los escenarios los resabios del modelo teatral que derivaba de la comedia áurea (Domínguez Ortiz 1983 y 1984), la traducción de Signorelli guarda especial importancia no sólo para la comprensión de esta enconada contienda teatral, estética e ideológica al mismo tiempo, sino también por lo que atañe a la repercusión que la misma pudo haber registrado en los circuitos culturales de la Italia del Settecento, donde en aquellos último años del siglo es posible reconocer una colonia de españoles nada despreciable, entre los que destacaba el nutrido grupo que remite a la diáspora de los jesuitas expulsos.

La comedia nueva o El café, segunda obra teatral de Moratín, fue redactada con toda probabilidad a mediados de $1791^{24}$, aunque el proceso de gestación debamos extenderlo a los años precedentes. La pieza guarda relación con otros dos textos del autor madrileño, la Lección Poética (1782) y La derrota de los pedantes (1789), fruto de estímulos culturales e intelectuales similares, pudiendo inscribirse todos ellos en la vertiente satírico-preceptiva, $\tan$ en boga en la literatura dieciochesca. Es el mismo Signorelli quien nos informa acerca del probable período de redacción de la obra: "Me alegro muchísimo -le escribe a Moratín congratulándose con el autor, luego de haber leído la pieza que el mismo Moratín le había enviado- que su retiro en las peñas de Alcarria le valió La comedia nueva. En mi carta del 20 de junio [de 1792], que le faltó a Ud., yo le decía así: 'No dudo el que su voluntario destierro le habrá de valer a Ud. alguna obra excelente' (....)" (en Mininni 1914: 417) La obra se había estrenado algunos meses antes, a principios de ese mismo año, después de haber superado la censura de las autoridades ${ }^{25}$, permaneciendo seis días seguidos en cartel en el Teatro del Príncipe, del 7 al 12 de febrero (Andioc-Coullon 1996, I: 427) ${ }^{26}$, lo que habla de una aceptación nada desdeñable entre el público madrileño.

Signorelli recuerda que en esta pieza su autor "espone una fedel dipintura (...) dello stato attuale del teatro spagnuolo" (Storia, IX: 183). Para ello Moratín se propone satirizar y enjuiciar el modelo dramático imperante que en aquellos años concitaba la adhesión del

\footnotetext{
${ }^{24}$ Disponemos de varias ediciones modernas de la Comedia nueva; entre ellas señalamos especialmente la espléndida edición de J. Dowling (1970), ampliamente documentada, y la más reciente editada por J. Pérez Magallón (1994) que incluye un exhaustivo aparato crítico-filológico. Todas las citas proceden de esta última edición.

${ }^{25}$ Sobre las vicisitudes que la obra debió afrontar antes de su representación -solicitudes, permisos, informes elevados a favor y en contra- en este último caso sobre todo por parte del comediógrafo Francisco Comella, quien se sintió aludido directamente a través del retrato que Moratín efectuó del protagonista, don Eleuterio, se remite a la bien documentada edición de J. Dowling (1970: 266-77). En la edición de Dowling puede leerse también el permiso del 2 de febrero de 1792 de Manuel de Valbuena que concede la autorización para la representación y publicación de la obra (1970: 266-7).

${ }^{26}$ Al respecto Signorelli recuerda que "che il pubblico di Madrid la vide con particolar diletto e l'applaudi" (Storia, IX: 185). Pocos meses después de su estreno, se publicó la primera edición. La obra volvería a representarse en Madrid ese mismo año, el 1 de diciembre, esta vez en el Teatro de la Cruz. La pieza subió a las tablas luego en 1793 (Príncipe, 2 de julio) y en 1799 (Príncipe, 27 de julio). Antes de la guerra de Independencia volvió a representarse en 1802 (Cruz, 23 de septiembre, 29 de noviembre y 5 de diciembre) y en 1807 (Príncipe, 2 de agosto; Caños del Peral, 31 de octubre y 2 de noviembre): todos los datos han sido tomados de R. Andioc y M. Coullon (1996, II: 663). Véase también J. Dowling, "Estudio sobreLa comedia nueva" (1970: 56-8), en la que se recogen dos breves reseñas periodísticas tomadas delCatálogo de A. M. Coe (1935: 47-8).
} 
público, especialmente las comedias heroico-militares, torpes imitaciones del teatro clásico nacional que, luego de la prohibición de los autos sacramentales en 1765 y de la comedia de magia a finales de los años 80', constituían el último reducto en el que se habían atrincherado los partidarios del teatro popular. Es decir, que es el mismo teatro el núcleo temático central en torno al cual se organiza la obra; el teatro, y de modo especial, el estado de abandono y de decadencia en que éste se encuentra en aquellos últimos años de la centuria, así como la necesidad de implementar una urgente reforma en los escenarios. En efecto, todos los que se han abocado al estudio de la Comedia nueva han resaltado el afán de crítica y la intención satírica allí presente, centrada en la impugnación de las comedias desarregladas que imperaban en los escenarios en aquellos decenios y ridiculizando a la vez a los malos poetas y comediantes pedantes que las llevaban a las tablas.

Apoyándose en el concepto clave de imitación de "la naturaleza en lo universal" (CN, a2), Moratín explicita en el prólogo los temas y la finalidad didáctica y moral que encierra la pieza, señalando que la obra "ofrece una pintura fiel del estado actual de nuestro teatro, aclarando que ni en los personajes ni en las alusiones se hallará nadie retratado" (CN, a2). Evidentes eran, sin embargo, las alusiones a Zabala y Zamora, Moncín, Cladera y Comella, principalmente a los dos últimos. Con Pérez Magallón, se podría decir que la pieza consiste en "el estreno de una comedia y en su fracaso" (1994: 42), por supuesto, desde la perspectiva ilustrada y de la estética neoclásica. El mismo Moratín es quien explica la novedad de su pieza al resaltar como medio "más conveniente" el de "presentar en el Teatro, castigados y expuestos al desprecio general, los vicios del Teatro mismo" (CN, a 4).

A este respecto, Vivanco observa que el autor español "en vez de quedarse en el terreno de la teoría o de los preceptos, desciende a la práctica y crea sus escenas y personajes, es decir se mete en el escenario" (1972: 149). No cabe duda alguna que Moratín traza de este modo un logrado laboratorio de metateatro en una fase crucial en la que las polémicas teatrales se hallaban a la orden del día, erigiendo esta pieza en un jalón más en la batalla que habían emprendido los neoclásicos por desterrar de los escenarios las expresiones y los modelos populares de derivación áurea.

Como se ha puesto de realce, el título de la obra constituye en verdad un juego de palabras que revela la preocupación central del autor -y la impronta polémica que el texto exhibe-, puesto que alude como comedia nueva a "lo que es precisamente crítica y negación del concepto mismo de 'comedia nueva', y a la vez, elemento imprescindible en la formación de la nueva comedia" (Pérez Magallón 1994: 31). La obra de Moratín se erige por tanto en vehículo insustituible en la batalla contra los modelos que los ilustrados refutan y se proponen desterrar de los escenarios los 'desarreglos' de las 'comedias nuevas', expresión de una fórmula que los neoclásicos, llevados por su rigor clasicista, conciben como directa derivación de la comedia áurea y que refutan en aras de un espectáculo reflexivo e instructivo. "Las comedias servían de pasto a la imaginación y muy poco al entendimiento: compensaban deseos reprimidos en la vida cotidiana en lugar de cimentar el sentido de la realidad y corregir las costumbres de los espectadores", anota Sánchez-Blanco (2002: 149). Si al público del XVII había que ofrecerle espectáculo y entretenerle, en el XVIII, siguiendo los nuevos cánones fijados por el racionalismo ilustrado, hay que deleitarle y al mismo tiempo enseñarle: "A mí me irrita, lo que a usted le divierte", le confiesa el virtuoso don Pedro a don Antonio en la comedia moratiniana (CN, 19). 
El duro enjuicimiento a la fórmula teatral que imperaba en los teatros de la península se expresa tanto a través de la severa crítica de Don Pedro, hombre sensato, racional y reflexivo, que se erige en portavoz de las ideas del autor, como por medio de la representación paródica de la 'comedia nueva' que está por subir a escena, El gran cerco de Viena, y que remite al modelo de la comedia heroico-militar que el autor refuta y satiriza y al que la crítica ha identificado, por sus innegables similitudes, con las de su gran adversario, Luciano Comella (1751-1812), siendo evidentes en este sentido las alusiones a la popular pieza El sitio de Calés (1790) del autor catalán.

Este propósito de crítica y de reforma teatral del cual es portador la comedia del madrileño, como se ha observado, fue percibido rápidamente por el traductor napolitano, quien se congratuló con su autor el mismo año en que la pieza subía a escena. En su carta del 12 de mayo de 1792, el italiano le recuerda a su amigo español sus largos años en Madrid y su condición de testigo directo, observando que "quien como yo, conoce la nación, los bandos teatrales, la inundación de poetillos y pedantones (...), bien comprende la dificultad que tenía que vencer un español para decir en una pieza teatral tantas y tan amargas claridades (...)" (en Mininni 1914: 417). Desde este mirador el dramaturgo italiano explicitaba su concepción del hecho dramático, y de modo particular, corroboraba su preferencia por la comedia dieciochesca española, sobre todo las de 'caracteres', ya expuestas previamente en el apartado que pocos años antes le había dedicado al comediógrafo madrileño en el sexto volumen de su Historia crítica de los teatros (Nápoles: Orsino, 1790).

\subsection{Reforma teatral, controversias estéticas y denostación personal}

Consciente de la aspiración instructiva y de los propósitos de reforma que exhibe la pieza original y que lo acomunan a su autor, Signorelli se apropia del texto moratiniano para trazar, a través de éste, una perspectiva personal en su batalla por la reforma de los escenarios en ambas penínsulas, reavivando así las polémicas con algunos de sus principales adversarios, y a quienes alude directamente en el texto. Se ha señalado ya que la versión teatral de Signorelli, aunque bastante cercana al modelo original desde el punto de vista lingüístico confirma en cuanto a sus propósitos y a la funcionalidad que el traductor le asigna, su libertad en el arte de traducir (Quinziano 2001: 276-81).

Ahora bien, aunque el italiano no dejó nunca de profesar su admiración y su solidaridad con la fórmula dramática del dramaturgo madrileño, las modificaciones operadas confirman en cierto modo la relativa autonomía con la que Signorelli tradujo e intervino sobre el texto original para la redacción de su edición italiana. Esta libertad en su aproximación a los textos moratinianos, manipulándolos y reelaborándolos en función de los gustos y los hábitos italianos y, también, según sus propias prioridades estéticas e ideológicas, alcanzan una emblemática confirmación en las últimas escenas de La commedia nuova, en las que, como el mismo traductor hace explícito ${ }^{27}$, se añaden no pocos diálogos con el claro propósito de acentuar tanto la comicidad como el carácter polémico de la pieza original.

El crítico partenopeo no sólo comprendió perfectamente los contenidos y la intencionalidad polémica ínsita en la comedia de su amigo, sino que vislumbró en ella una

\footnotetext{
27 "Mi valgo in tal versione, poche volte per altro, di qualche libertà per iscolpir vie più i caratteri onde meglio appressarli a quelli de' nostri paesi”, alega, en efecto, en las páginas iniciales del cuarto volumen de susOpuscoli Vari (IV: XIII).
} 
ocasión insustituible para proseguir la larga disputa que desde hacía años lo enfrentaba a Cruz, García de la Huerta, Sempere y Guarinos y, de modo especial, al abate catalán Llampillas $^{28}$, a quienes, con tonos que introducen la denostación personal, llama "tagliacantori letterari ed infedeli adulatori di se stessi e dei difetto del teatro nazionale" (Storia, 1813, VI: 133). Giuseppe Rossi recuerda que Signorelli "se vale del espíritu ortodoxo neoclásico de Moratín y de su época en España, como de un instrumento práctico y teórico para participar a su manera en la batalla en (...) defensa del teatro tal como ellos lo entienden: medio literario y fin moral" (1974: 133). Por su parte, refiriéndose al caso más específico de la traducción de la pieza moratiniana, Mariutti opina con razón que Signorelli "se entusiasmó con la atinada sátira y la consideró de lo más oportuno frente a las polémicas que había tenido con Llampillas" (1960: 776).

No es éste el lugar para adentrarnos en la vastidad de temas y en la amplitud de posiciones que fueron plasmando una contienda en la que a los contenidos de carácter cultural y estético, y de la que sin duda no se hallaba exenta la famosa polémica cultural ítalo-española que concentró la atención de los literatos de ambas penínsulas a lo largo del último tercio de la centuria, fueron añadiéndose otros aspectos mucho menos nobles que dieron lugar a enfrentamientos y rivalidades personales, a recelos, envidias y antipatías. En la controversia que el italiano entabló con Vicente García de la Huerta y Ramón de la Cruz, estos últimos ingredientes jugaron un papel nada desdeñable. Aprovechando el dato de que a Llampillas se alude en el texto moratiniano $(\mathrm{CN}, 62)$, como le recordará el mismo Signorelli al abate en la polémica dedicatoria que le dedica (Opuscoli, IV: IV), al tiempo que acentúa aún más los rasgos caricaturescos de don Hermógenes/Ermogene, el napolitano opta por referirse directamente también a sus otros dos detractores, Ramón de la Cruz y el autor de La Raquel:

D. Hermógenes.- Piense usted lo que quiera; yo pienso de su obra lo que ha pensado el Público; Pubblico.

Pero soy su amigo de usted; (...) porque como circa

Dice Platón y el abate Lampillas... (CN, p. 62) come
D. Ermogene.- Pensate quel che volete; io penso del vostro lavoro quel che e ha pensato il

Sono però vostro amico, né mi ritratto

l'apologia che vi ho accennato (...); perché

dice Platone e l'abate Lampillas, e di poi la Huerta, e La Cruz (Cni, 45; el subrayado es nuestro)

La disputa que el erudito napolitano entabló con ambos dramaturgos venía de lejos. El hispanista italiano se hallaba enfrentado con Ramón de la Cruz, a quien nuestro autor gustaba llamar "vulgar saynetero", y con el autor de La Raquel desde los años de su estancia madrileña. Ambos, no se olvide, habían sido fuertemente atacados por el círculo de literatos ilustrados agrupados en torno a Nicolás Moratín. El crítico y filólogo Farinelli ha

\footnotetext{
${ }^{28}$ Sobre las controversias teatrales que Signorelli entabló con dramaturgos y preceptistas españoles, en especial Llampillas, García de la Huerta y Ramón de la Cruz, véanse C. Mininni (1914: 85-9: Huerta; 118-21: Llampillas y R. de la Cruz), A. Mariutti de Sánchez Rivero (1960: 776-8) y Soriano Pérez-Villamil (1980: 120-3). Entre las aportaciones más recientes referidas al tema se señalan E. Liverani (1995: 125-48) y J. C. de Miguel y Canuto (1996, II: 625-52). En una perspectiva más amplia, sobre la polémica cultural ítalo-española del último tercio de la centuria y que vio entre sus principales animadores a los jesuitas Tiraboschi, Bettinelli, Andrés y Llampillas, véanse W. Hempel (1965: 115-20) y Soriano Pérez-Villamil (1980: 109-125).
} 
observado con razón que "le accuse lanciate da Napoli Signorelli (...) contro il García de la Huerta, il Llampillas, l'Arteaga, il Ramón de la Cruz sono un'eco delle accuse ben più aspre ed ingiuriose che i due Moratín (...) lanciavano senza tregua ai rivali compaesani” (1929, II: 307-8).

La batalla por la reforma de los escenarios nacionales había afianzado en el dramaturgo napolitano el carácter colectivo de la amistad y al mismo tiempo un claro sentido de colaboración grupal. Esta expresión de sociabilidad y de sensibilidad compartida, que presidió las relaciones entre los ilustrados, fue determinando en el autor italiano un sentido de pertenencia cultural bien definido, de plena identificación con el grupo reformista ilustrado. Trascendentales en dicha perspectiva fueron, pues, las relaciones que el literato napolitano había cultivado a los pocos meses de haberse afincado en Madrid, de modo especial con el autor de La petimetra, y que le procuró también no pocas enemistades. Si Ramón de la Cruz tuvo no pocas diferencias con el padre de Leandro y con su círculo de amigos, García de la Huerta, quien polemizó con la mayoría de los escritores del círculo ilustrado madrileño, será por lo general el blanco de los ataques y de las burlas que le dirigen los neoclásicos, como nos confirman el emblemático poema épico-burlesco La Huertaida (Moratín 1995: 519-22) que el autor de la Comedia nueva le dedicara y el más ofensivo epitalamio de Iriarte, quien en sus versos acabaría acusando al extremeño poco menos de demente.

El dramaturgo partenopeo se vanaglorió en reiteradas oportunidades de las amistades que había logrado establecer en su "caro soggiorno" madrileño, y en más de una ocasión hizo alarde de ellas con el claro propósito de refutar las injustas acusaciones que le movían sus adversarios. De este modo el crítico partenopeo aspiraba a legitimarse como amigo y defensor de la cultura española, como es posible corroborar a través de las polémicas que, ya de regreso a su ciudad natal, mantuvo con otros dos importantes -y prestigiososexponentes de la cultura hispanoitaliana del dieciocho, los ex jesuitas expulsos Juan Andrés y Esteban de Arteaga. Al mismo tiempo, las diatribas salpicaron también al erudito Sempere y Guarinos ${ }^{29}$, de ideas ilustradas como los amigos del napolitano. Al elogiar y tomar partido por Cruz y García de la Huerta (1785-87, I: $232-8$ y III: 102-22, respectivamente), era inevitable que el crítico italiano acabara enfrentándose también con el literato alicantino.

Si la querella reconocía en su origen dos percepciones radicalmente disímiles sobre los contenidos, el valor y las virtudes de la cultura hispánica e italiana, respectivamente condicionadas por la vena apologética y nacionalista de la que las posiciones de ambos autores se alimentaban, a la que se sumaba la adhesión a dos modelos teatrales radicalmente enfrentados, con los años la disputa fue tiñéndose de contenidos muchos más pueriles y menos nobles, por lo que las divergencias de un principio, tanto artísticas como teatrales, fueron desplazándose al más delicado campo de la denostación personal (Storia 1813, IX: 234), avivadas por la antípatía y la animosidad recíprocas.

\footnotetext{
${ }^{29}$ Numerosas son las ocasiones en que Signorelli ataca al erudito alicantino, "Giovanni Sampere, o dottor Guarinos che siasi” (Storia, IX: 70), al que llama en tono irónico "prelodato bibliografo dei viventi”, en alusión a su Ensayo de la biblioteca española (1785-89). Signorelli polemizó con él a través de las páginas de su Storia critica al analizar las tragedia Sancho García de Cadalso (Storia, IX: 70-2) y la Numancia destruida de Ignacio de Ayala (Storia, IX: 75-9). Por su parte Sempere y Guarinos, no perdió ocasión en denostar al literato italiano sosteniendo, entre otras arbitrarias acusaciones, que su "poca instrucción y alusiones acerca de nuestro teatro son bien notorias" (1969, I: 234); posición que contrasta con la más juiciosa de Leandro F. de Moratín, quien en la biografía que le dedica a si padre, asevera que "ningún crítico extranjero ha hablado con mayor acierto que Signorelli del mérito de los dramáticos españoles” (en Obras: XIV).
} 


\section{2. Vicente García de la Huerta: 'acuto' y 'gongoresco ridicolo'}

La génesis de la polémica, enmarcada en la naciente edad de los nacionalismos, se hallaba en las belicosas palabras que el extremeño había dejado estampadas en el controvertido Prólogo que antepuso a su Theatro Hespañol (1785-86) -"collezione che non è ragionata, né completa, né scelta", según Signorelli (Storia 1813, IX: 124-5)-, y en el que se atacaba a los Quadrio, Tiraboschi y Bettinelli. Huerta le recrimina a los italianos el haber denigrado la cultura ibérica, ya que en sus escritos habían achacado a los españoles ser los principales responsables de la "corrupción" del gusto en que se hallaban sumidas las letras italianas. "El tocar el punto'más vulnerable de su psicología, 'la patria', comenta Pérez -Villamil, encendió en el ánimo de Signorelli esa pasión contra él, que se veía fomentada por el ambiente literario de estos años y que la iracundia y mordacidad del autor de Raquel excitaban más y más" (1980: 121).

Las apreciaciones que enhebran el Prólogo de García de la Huerta, quien se solidariza con el apologista Llampillas en su defensa del teatro español, desataron un diluvio de críticas y revelan su poca consistencia teórica. Más que una polémica de índole cultural constituyen un ataque directo de carácter personal, una larga diatriba contra el crítico napolitano en el que no se hallan ausentes los tonos de carácter xenófobo (Ríos Carratalá 1987: 210-4). El propósito de Huerta es el de denostar y desprestigiar públicamente al hispanista italiano, insistiendo sobre su supuesta ignorancia acerca del teatro español, algo que -leyendo su Historia crítica del Teatro- no hacía honor a la verdad. Para ello el dramaturgo extremeño no duda en forzar los textos y en tergiversar las opiniones de su rival, rebatiendo las consideraciones que éste había trazado en la primera edición de la Storia critica. En su poco afortunado prólogo, García de la Huerta refutaba las observaciones del napolitano sobre el origen de los autos sacramentales y trazaba una defensa del género sacro. La degeneración de los autos en las tablas habían provocado la fuerte hostilidad de los neoclásicos, quienes instaron a que estas brevs piezas de origen sacro fuesen prohibidas. Del mismo modo rebatía "los comentarios de Napoli-Signorelli sobre los teatros de Madrid [Príncipe, Cruz y Caños del Peral], las compañías que en ellos trabajaban y sus asiduos grupos de aficionados, los famosos 'chorizos' y 'polacos' “ (Ríos Carratalá 1987: 212) ${ }^{30}$. El napolitano había aseverado en su primera edición de la Storia critica dei teatri (1777) que ambos bandos teatrales habían prácticamente desaparecido, aunque ello, más que una constatación, correspondiese más bien al deseo que nutrían los neoclásicos de que los aficionados fuesen alejados de los teatros, por lo que la observación no eran del todo injustificadas.

Las acusaciones que el autor del Theatro Hespañol le movió al hispanista italiano (1785-86: VIII-XXIII) eran sumamente severas, argumentando con tonos despectivos que "incluso los menos aficionados al teatro sabían lo que ignoraba Pietro Napoli Signorelli", palabras que sin duda hirieron fuertemente el orgullo del autor napolitano. En su prólogo el dramaturgo español ponía de realce las “impertinentes ignorancias en que incurrió el Dr.

\footnotetext{
${ }^{30}$ Sobre la disputa García de la Huerta-Napoli Signorelli véanse las pp. 210-214 de la citada monografía de Ríos Carratalá (1987), quien carga más las tintas sobre el extremeño en cuanto a las responsabilidades por el áspero tono del debate que los enfrentó, apuntando que en Huerta "tan sólo opera un deseo de defensa a ultranza de nuestro teatro, de no admitir ninguna crítica foránea", confirmando una posición xenófoba (1987: 213). En cierto modo distinta es la posición que traza Pérez-Villamil, quien resalta la parcialidad y la pasión en los juicios vertidos por Signorelli (1980: 120); aspectos que en honor a la verdad deben ser atribuidos a ambos contendientes.
} 
Signorelli" (1785-86: VII-VIII), desarrollando sus argumentos con el fin de poner al descubierto la poca sabiduría y la mala fe del crítico italiano, a quien -injustamente- acusa de agraviar y de desmerecer el teatro peninsular. Como hemos opinado en otra oportunidad "aunque en más de una ocasión aflora su inconfundible amor patrio, expresión de un cada vez más acentuado nacionalismo cultural que ha comenzado a abrirse paso en la Italia de finales del siglo, anunciando el proceso de emancipación y unificación nacional que acabará imponiéndose a lo largo de la siguiente centuria, los escritos y el vasto epistolario del dramaturgo italiano se hallan salpicados de notas y de consideraciones en las que de modo incuestionable emerge su interés y su sincera admiración hacia la cultura española", pudiéndose concluir que su obra nos confirma por el contrario "a un erudito íntimamente vinculado a las ideas de su siglo, respetuoso de la cultura hispánica y empeñado en difundir sus cualidades y sus expresiones más estimables, por supuesto desde su mirador racionalista y neoclásico" (Quinziano 2003: 242-3).

La respuesta del erudito napolitano -orientado, como es sabido, a la polémica y confrontación- por supuesto no se hizo esperar, aunque cuando salió a la luz en 1790 la segunda edición de su obra mayor, hacía ya algo más de dos años que el autor extremeño había fallecido. Signorelli dedicó allí varias páginas de su último apartado a examinar los 'teatros materiales', que luego serían ampliadas en su última edición (Storia, IX: 221-236), refutando las acusaciones de García de la Huerta, con el propósito de defenderse de la "tremenda batteria fluttuante" (Storia, IX: 223), como el mismo napolitano señaló, que sobre él se había abatido. En estas páginas, luego de referirse a las razones que habían dado origen a las rivalidades entre los dos bandos en los que se habían dividido los aficionados madrileños, avalando sus apreciaciones en su calidad de testigo directo, destaca la falta de raciocinio del autor español, a quien le reprocha una doctrina poco sólida y arrogante. Emerge en estas líneas y en toda su intensidad la vena la polémica de Napoli Signorelli, quien alude al autor de La Raquel como aquel que tuona [...] ne' Caffè e ne' passeggi e ne' papelillos che scarabbocchiava, servendogli d'eloquenza l'arroganza" (Storia, IX: 234).

Es evidente que esta controversia que los dos dramaturgos mantuvieron y fueron alimentando encuentra sus fundamentos en el temperamento polémico que distinguió a ambos contrincantes, más proclives a la disputa que al diálogo y al debate sereno, lo que confirma que las querellas en no pocas ocasiones se nutrían de aspectos y componentes que no siempre echaban sus raíces en cuestiones estrictamente estéticas. Como destaca Ríos Carratalá, el autor extremeño, cuyo Theatro Hespañol lo llevó a polemizar con un arco más bien amplio de compatriotas (desde Vargas Ponce hasta Mayans, pasando por Jovellanos, Nicolás Moratín y Forner), "adulteraba a menudo las discusiones por la presencia de elementos personales y pueriles" $(1987: 15)^{31}$.

Desde esta perspectiva, puede aseverarse que Huerta busca constantemente el error o los defectos del adversario, llegando en varias ocasiones a deformar el pensamiento de su interlocutor, como en el caso del literato italiano (Ríos Carratalá, 1987: 210-4). Del mismo modo el napolitano no pierde ocasión para lanzarle sus dardos todas las veces que se le presenta la oportunidad, principalmente a través de las páginas de suStoria critica de' teatri en las que, precisamente, no escasean las alusiones despectivas: "uomo torbido di

\footnotetext{
${ }^{31}$ Sobre las polémicas a las que dio lugar el Theatro Hespañol, se remite a R. Pellissier (1918: 142-8) y al más reciente apartado V.3 del texto de Ríos Carratalá (1987: 234-57). Sempere y Guarinos tomó claramente la defensa del autor extremeño, elogiando de modo desmesurado el Theatro Hespañol (1782-85, III: 109-18).
} 
carattere" (Storia, VI: 196), "acuto Huerta" [en sentido irónico] (Storia, VI: 199), "gongorista [y...] gongoresco ridicolo" (Storia, IX: 104), son algunos de los epítetos que nuestro autor dejó estampados. Del mismo modo traza un extenso y demoledor juicio sobre su tragedia Raquel (Storia, IX: 96-132), en la que percibe "falta de invención e ingenio", inexactitudes históricas e inconsistencias dramáticas, acusando a su autor de haber copiado a Diamante, de quien empero, pone de realce, había olvidado incluir las virtudes de su modelo original ${ }^{32}$. Aunque el literato partenopeo asevera que la desaparición del autor de La Raquel, en marzo de 1787, lo había llevado a respetar su memoria, declarando tan sólo pocos meses después que "habiéndose muerto" Huerta, había "moderado los golpes más reacios" (en Mininni 1914: 371), lo cierto es que el crítico napolitano prosiguió la controversia y continuó atacándolo con singular dureza, como puede corroborarse en los añadidos de la sucesivas ediciones de su obra monumental en 1790 y 1813 , y de esta referencia -en clave polémica- en las escenas finales de su traducción de la comedia moratiniana, alimentando una disputa que, si en sus inicios fue de índole estética, acabó desplazándose hacia el terreno menos edificante de la diatriba y la enemistad personal.

\section{3. Ramón de la Cruz: 'poetilla' y 'vulgar sainetero'}

Es conocida la visión despectiva que, al examinar los sainetes que poblaban los escenarios madrileños del dieciocho, Signorelli dejó estampada, denostando tanto el género, que no encajaba en su cánon estético, como a su autor más representativo, el célebre Ramón de La Cruz, "poetilla (...) che tiraneggiava i commedianti nazionali" (Storia 1813, IX: 183). Con el popular sainetista nuestro autor mantuvo también por varios lustros una enconada polémica, plagada de réplicas y contrarréplicas que, al igual que en el caso del dramaturgo extremeño, no se hallaban exentas de fuertes -y recíprocos- tonos de animosidad personal. Si al periodista Nipho se debieron los ataques más explícitos y demoledores, el crítico napolitano no perdió ocasión en fustigarlo, por su afección al teatro breve de carácter popular, ampliamente impugnado por los partidarios de la nueva estética neoclásica, y de modo especial a causa de los ataques que el dramaturgo madrileño había lanzado contra su amigo Nicolás Moratín. Por su parte este último, Félix de Samaniego y Tomás de Iriarte, entre otros, censuraron severamente el modelo teatral de Ramón de la Cruz, mientras que el madrileño por su parte, a todos ellos les respondió de modo indirecto, satirizándolos colectiva y, en algunos casos individualmente en sus breves piezas teatrales.

Si en la primera edición de su Storia critica, el crítico partenopeo observa que Cruz "ha lo stile umile e di messo e batte lo stramazone tosto che vuol nobilitarlo, a ciò non gli nocerebbe gran fatto sempre che sapesse scegliere il genere di commedia conveniente alle sue forze" (Storia, 1777: 413), en la sucesiva edición publicada a finales de los años 80', la crítica al dramaturgo madrileño se hace aún más descarnada. Sucede que algunos años

\footnotetext{
32 José García de la Huerta, uno de los hermanos del extremeño, recuerda en sus Cartas desde la Italia (Mss. B.N.M., 6482-83) que la célebre tragedia había sido leída, entre otros distinguidos eruditos, por el marqués célebre Albergati, quien había mandado «mil elogios al Autor y gracias al Traductor por haber puesto a la Italia en estado de gustar las bellezas que en dicha pieza se contienen» (Plasencia, 3 de junio 1784, fol. 88 r.), para concluir, contradiciendo y polemizando con el hispanista napolitano, que laRaquel, podía «ya que no excederla, competirla en la perfección" a la Mérope de Maffei, "pues aunque D" Pedro Napoli Signorelli no hace de ella en su Historia Crítica más elogio que de nombrarla, ha merecido los mayores de los primeros sabios de España, Francia, Italia y Alemania, Portugal y las Américas, y después de impresa en Madrid en 1778, varios respetables cuerpos de inteligentes en la Poesía la han juzgado modelo perfectísimo de estas composiciones» (Plasencia, 3 de junio de 1784 , fol. 88 v.).
} 
antes, Cruz, había lanzado un ataque frontal al napolitano, rebatiendo las objeciones que éste había hecho a sus sainetes y acusándolo de demostrar en sus consideraciones "ignorancia, ostentación o malicia" (Theatro Español, 1786, I: XXXVI-XXXVII). Mientras el napolitano le reconoce a Cruz "mucha destreza" en el retrato de la "ínfima plebeya" (Storia, 1789, IV: 87-88), en la sucesiva edición de su obra monumental, su juicio es más severo, condimentado con algunas consideraciones a pie de página de índole persona防, que corroboraban la distancia e inamistad que se había ido instaurando entre ambos dramaturgos y cuyas génesis se hallaban en las disputas durante los largos años en que el napolitano había residido en Madrid. En estas páginas, dedicadas al sainete, Signorelli anota que el comediógrafo español "potrà aver anche fantasia per inventare e ben disporre favole nuove compiute, ma in tanti anni non l'ha certamente manifestata. In effetto, (...) egli si è limitato a tradurre alcune farse francesi, e particolarmente di Molière. Ma invece di apprendere di sì grande maestro l'arte di formar quadri compiuti di giusta grandezza simil al vero -concluía con ácida ironía-, egli ha rannichiate, poste in iscorcio disgraziato e dimezzate nel più bello le di lui favole" (Storia, 1790, VI: 87-88) ${ }^{34}$.

Si en algunas ocasiones el dramaturgo español es directo y frontal, en otras no pierde ocasión en responder a las acusaciones que Signorelli le había lanzado, aunque se cuida de mencionarlo directamente. Por lo que respecta a la defensa de su Manolo y de sus otras piezas que ocupaban los escenarios de la capital obteniendo el favor del público, y enjuiciadas implacablemente por el hispanista italiano (Storia, 1813, IX: 190-1), Cruz se defiende declarando en la presentación de su Colección de Saynetes que "para que nadie por esta relación forme, como pudiera, juicio de que de que mi tosco pincel sólo se ha empleado en estas humildes copias, se representan las 15 piezas de los dos primeros volúmenes de mi Teatro, sin Lavapiés, sin Maravillas, sin presidiarios, sin borrachos, y sin arrieros ni escenas de sus costumbres" ${ }^{135}$. Aunque no los nombra ni se refiera a ellos de modo directo, a nadie se le escapaba que las alusiones iban dirigidas a Quadrio, Bettinelli, Tiraboschi y, de modo aún más acusado, a Signorelli, al recordar con tonos sarcásticos que los eruditos italianos se habían ocupado "sobre toda la poesía, y toda la literatura, y llamáronla de todos los teatros de este y del otro mundo, in 'saecula saeculorum' (en Mininni 1914: 120; el subrayado es nuestro).

Al denostar -ya sea directa o indirectamente- en 'su' Commedia nuova a sus rivales y antagonistas, por lo general introduciendo una conversación sobre el teatro entre dos o más

\footnotetext{
${ }^{33}$ En respuesta a las acusaciones de algunos años antes que le había formulado Cruz y sostenidas también por el erudito alicantino Sempere y Guarinos, puede leerse la siguiente nota a pie de página: "Dopo la mia partenza [de Madrid en 1783], egli [Cruz] ha gridato, ha fatto gridar Sempere, ha malmenato il Signorelli all'usanza de' suoi presidianti e Manoli. Ma potè egli mai distruggere ciò che è storia pura? Potè mai fare ch'egli non fosse sempreil poetilla La Cruz?; Storia, 1789, VI, p. 89. La misma nota, un poco más amplia, fue incluida también en la tercera y definitiva edición (Storia, 1813, IX: 194).

${ }^{34}$ Como en otras oportunidades, el autor de la Storia critica dei teatri no pierde ocasión para evocar su amistad con diversos autores españoles con el propósito de legitimar sus juicios y consideraciones. Así, pro ejemplo, recordará, que "un degno poeta spagnolo di questi tempi [Leandro Moratín?]" en una misiva redactada en Madrid a principios de octubre de 1789 , le comenta que hace pocos días ha asistido a la representación de una loa del popular sainetista que se representa en el Teatro del Príncipe, aclarando que "ayer la vi y ni yo ni cuantos asistieron a ella, pudimos entender una palabra, tan alegórica, y metafísica es la maldita Loa" del madrileño, Storia, 1813, IX, p. 193, nota a.

${ }^{35}$ R. de la Cruz, Prólogo a su Teatro, o Colección de los Saynetes y demás obras dramáticas de D. Ramón de la Cruz (Madrid, Imprenta Real, 1786-1791, 10 vols.), cit. en M. Coulon (1994: 11).
} 
personajes de ficción, Signorelli no hacía más que echar mano a un recurso que el mismo Ramón de la Cruz por otra parte había adoptado ya en varias ocasiones, como es posible corroborar en sus sainetes de parodia, en aquéllos en los que se refieren a la polémica literarias o en sus piezas de costumbres que mejor que ninguna otra se prestaban a la polémica y a la abierta contienda. El crítico napolitano percibió muy bien este procedimiento paródico esgrimido por el popular comediógrafo madrileño en clave de polémica, llevando a las tablas sátiras contra sus críticos e impugnadores.

Al referirse al sainete dedicado a la tragedia clasicista que ocupa la acción en Manolo (1765), el literato italiano advierte que el autor había plasmado una trama cuya finalidad principal era burlarse y "mettere in ridicolo gli scrittori di tragedie e l'osservanza delle unità" (Storia, IX, p. 190) ${ }^{36}$. En dicha perspectiva, en la escena VII del último acto de la versión italiana de la pieza moratiniana, Signorelli pone en boca de don Hermógenes, modelo de falso erudito, y, según palabras del autor madrileño, ejemplo "del compendio de todos los malos poetas dramáticos que escribían en aquella época” (en L F. Moratín 1970: 165), las siguientes palabras, distanciándose parcialmente del texto original:

"Dirò che ve ne sono delle peggiori [commedie] citate dal [abate Javier] Llampillas come eccellenti. Diró che vi sono osservate le regole, se non vi è connessione, questo è, como dice il gran Vicente Huerta, perché un grande ingegno non bada a queste bagattelle; tacerò tutti i suoi difetti, e la porrò -concluye con evidente tono irónico- al pari delManolillo del rinomato La Cruz" (CNi, 44).

Comparando el diálogo con el que ofrece la pieza española, resalta rápidamente la diferencia y el propósito del traductor, orientado a reavivar y actualizar la polémica con sus tres adversarios, apropiándose parcialmente del texto de su amigo español. Conviene recordar que Moratín, aunque no esconde su espíritu irónico y de polémica, apoyándose en el notorio principio neoclásico de imitación de la naturaleza en lo universa ${ }^{\beta 7}$, había evitado -salvo en el citado caso de Llampillas- toda alusión directa y crítica frontaß ${ }^{8}$.

\subsection{Llampillas: 'apologista' e 'ignorante'}

Mucho más largas, directas y vehementes fueron, sin embargo, las diatribas y acusaciones que se cruzaron Signorelli y el jesuita expulso Xavier Llampillas, contra el cual el literato napolitano redacta su Discorso storico-critico (Nápoles: 1783), refutando los comentarios del crítico español, y a quien en clave polémica el napolitano le dedica su

\footnotetext{
${ }^{36} \mathrm{M}$. Coulon valora el sainete de costumbre teatral como instrumento de polémica y de réplica, "en el cual los cómicos desempeñaban su propio papel y debatían en las tablas los sucesos de la vida de las compañías. Desde 1764, burlándose de Clavijo y Fajardo y de su Pensador (...), Ramón de la Cruz supo aprovechar las posibilidades de esta clase de sainetes, desechando poco a poco el argumento que prevalecía hasta entonces (...) para anclarlo en la actualidad del momento; de este modo se creaba una complicidad entre los cómicos -o a través de ellos, el propio sainetista- y un público que así tenía la ilusión de acercarse al mundo que le encantaba", para subrayar luego que el madrileño utilizó "la popularidad de los actores para expresarse por su boca y solicitar indirectamente el apoyo del público, a quien halagaba haciéndole testigo en un debate del que en realidad estaba excluido", (Coulón 1995: 337).

${ }^{37}$ Moratín a este respecto precisa que su pieza "ofrece una pintura fiel del estado actual de nuestro teatro" y aunque sostiene que "ni en los personajes, ni en las alusiones se hallará nadie retratado" (CN, a 2), como es bien sabido, son innegables las referencias al modelo teatral propugnado por C. Cladera, G. Zabala y Zamora y, sobre todo, L. Comella, con quien el comediógrafo madrileño mantuvo una larga y enconada polémica.

38 “D. Hermógenes- (...) y la citaré con elogio: diré que hay otras peores; diré que si no guarda reglas ni conexión , consiste en que el Autor era un grande hombre; callaré sus defectos... "(CN, 61).
} 
traducción de la comedia de Moratín (CNi, 3-4). La disputa que Signorelli entabló con el jesuita catalán afincado en Génova no se halla separada de la famosa polémica cultural ítalo-española que, en defensa de la cultura y el teatro españoles, este último había trabado con los italianos Tiraboschi y Bettinelli. En esta contienda, Llampillas obtuvo el apoyo, entre otros, del alicantino Sempere y Guarinos, para quien los preceptistas italianos "no solamente han incurrido en todas las equivocaciones de los ultramontanos acerca de nuestra literatura, sino que han añadido otras mayores, qual es el atribuir a nuestra nación la decadencia y corrupción del gusto" (1782-85, III: 162). Como es sabido, Llampillas refutó con vehemencia las duras acusaciones que ambos italianos habían lanzado a la cultura española, publicando en lengua italiana entre 1788 y 1791 su Saggio Storico-Apologetico en defensa del teatro español, texto que casi inmediatamente fue traducido al español por Josefa Amar y Borbón (Zaragoza: Miedes, 1782-84). El jesuita catalán explicaba de este modo los propósitos claramente apologéticos de su obra:

Ammaestrato da così saggi insegnamenti, dettati non meno dalla buona morale, che dal buon gusto, protesto di scrivere quest'Apologia contro le pregiudicate opinioni che mostrano di nutrire a disfavore della letteratura spagnola il Sig. abate Girolamo Tiraboschi e il Sig. Severio Bettinelli, (...) Altro noi non pretendiamo che difendere la nostra Spagna da quei pregiudizi in forza de' quali è creduta da non pochi nemica del buon gusto e corrutrice della letteratura (...) Impugneremo i pregiudizi (...) e ci sforzeremo a mostrare, che non fu la Nazione Spagnuola quella che corruppe il buon gusto dell'antica letteratura italiana; ma che anzi a nessuna delle Straniere Nazioni (... ) tanto debbono le Romane antiche lettere, quanto alla spagnola" (1778-81, I: 4-8).

La finalidad que persigue Lampillas, pues, es la de restaurar el honor y la gloria de la cultura española. En este sentido se lamenta de los que acusan injustamente a España y no se dignan concederle un lugar entre las naciones cultas de Europa. Conviene señalar que, si bien en el plano de la valoración de la cultura española que efectúa un sector importante de la crítica italiana dieciochesca, desempeña un rol de gran relevancia la incidencia de prejuicios bien arraigados por decenios, cuando no siglos, la visión de Signorelli en este aspecto se apartaba de modo inequívoco de la que habían vertido sus compatriotas Bettinelli, Quadrio y Tiraboschi. Aunque en su texto apologético reconocía las virtudes de la Storia critica de' teatri, precisando que "forse niuno degli stranieri ha scritto intorno al teatro spagnuolo con uguale cognizione della nostra e delle nostre opere" (1778-81, I: 5-6), el jesuita desterrado atacaba sin concesiones a Signorelli. Al respecto, al recordar el amistoso encuentro entre ambos autores que había tenido lugar en Génova en 1779, Mininni anota que "nel 1781, il Lampillas aveva terminato gli ultimi due volumi del Saggio apologetico, e, dimentico del patto amichevole, stretto due anni prima col Napoli Signorelli contro di lui aveva diretto quasi tutto il quarto della seconda parte ${ }^{39}$.

Ahora bien, si Lampillas, claro defensor del drama español áureo, no pierde ocasión desde las páginas del cuarto volumen de su Saggio storico-apologético (1781) para censurar y zaherir al literato napolitano, éste a su vez le responde dos años más tarde con la misma vehemencia, ya sea primero a través de su Discorso Storico-critico, ya sea algunos años más tarde, primero en 1790 y luego en 1813, a través de las sucesivas ediciones de la Historia crítica de los Teatros, en las que amplía los apartados que había dedicado al drama español del XVIII ${ }^{40}$. En la primera obra, la cual, en palabras del anónimo redactor de las Effemeride letterarie (19-07-1783; vol. XXIX: 229) resalta "la erudición, la elegancia, la

${ }^{39}$ Mininni, 1914, p. 68, nota 3. 
fuerza, la urbanidad y la moderación" del autor italiano, éste aclara que el amor y respeto hacia la cultura española, no debe confundirse con la exaltación hiperbólica de España o con la atribución a ella de 'glorias imaginarias ${ }^{41}$, como en su opinión se deriva del texto apologético del abate catalán.

Emblemática de esta larga y animada polémica teatral que, como otras en acto en aquellos decenios del setecientos combinaban cuestiones teóricas y estéticas con dosis de rivalidad y antipatía personales, se nos revela la dedicatoria de la traducción moratiniana que, en tonos polémicos, el napolitano le envía al catalán en abril de 1795 y que el italiano antepone a su traducción:

Mi è pervenuta una commedia spagnola in prosa scritta da un pregevole autore (...), mio amico don Leandro Fernández de Moratín, intitolata La commedia nuova. Io che serbo e serberò sempre dolce memoria della nazione, (...) chene detesto soltanto gli Huerta pedanti, orgogliosi e villani, e gli audaci meschini autorelli plebei, come i La Cruz e i Sempere [y Guarinos], e i finti amici del paese (...) ho voluto impiegar qualche giorno in convertir tale commedia in italiano (...) e dar così (...) prova dell'amor che nutro per ciò che mi sembra buono, nasca dovunque (...) ( $\mathrm{CNi}$ : 3 ; el subrayado es nuestro)

Y luego de reseñar muy someramente el eje temático sobre el que discurre la pieza, a saber 'lo stato attuale del teatro spagnolo', y aprovechar la ocasión para insistir sobre el escaso conocimiento que sobre el tema ostentaba el crítico catalán a raíz de su larga ausencia y lejanía del reino, le recuerda cáusticamente que su nombre aparece citado en el texto del comediógrafo madrileño:

Verte questo componimento sullo stato attuale del teatro spagnolo, che voi non avete potuto mai sapere trovandovi da sì gran tempo in Italia. Voi che non credeste all'evidenza esposta semplicemente nella mia Storia de' Teatri (...), leggerete che con men torvo ciglio e con più pacato cuore la graziola dipintura delle medesime verità fatta da un nazionale culto, benemerito del teatro, e buono scrittore. A voi dunque -concluía polémicamente- dedico la mia versione, non sapendo rinunziar al merito di convertirvi, in grazia dell'abboccamento che

\footnotetext{
${ }^{40}$ Sobre la larga polémica que el hispanista napolitano mantuvo con Lampillas, cfr. G. Mininni (1914: 84-9) y E. Liverani (1995: 125-48).

${ }^{41}$ Dice al respecto Signorelli: "Io amo la Spagna colla letteratura, che l'adorna, ma non credo necessario, per bene amarla, l'attribuirle glorie immaginarie", manifestando su adversión hacia las apologías que, después de "una vampa momentanea, passano di moda e muoiono nel buio"; Discorso storico-critico, cit. en Effemeride Letterarie, vol. XXIX, 19-07-1783: 228 y 227, respectivamente. De todos modos, no puede silenciarse que los juicios vertidos por el mismo Signorelli, en más ocasiones, se hallan orientadas a demostrar la supremacía de la cultura italiana sobre la española y las restantes de Europa, como manifestación de un cada vez más difundido sentimiento nacionalista pre-risorgimentale que caracteriza a muchos intelectuales en la Italia de finales del XVIII. Sin negar los ribetes de excesivo amor patrio que guían muchas de las consideraciones del napolitano, no debe subestimarse el apreciable esfuerzo que el autor italiano realizó en pos de una más equilibrada apreciación de la escena española, difundiendo sus méritos en las letras italianas, donde los enemigos y los prejuicios hacia la cultura hispánica no escaseaban. Errado y por lo demás forzado sería acusar al napolitano de "hispanofobia", actitud que en cambio serpentea con evidencia en los escritos de sus compatriotas y amigos Tiraboschi y Bettinelli. Ciertamente el literato italiano en varias ocasiones revela este empeño en resaltar la producción literaria de su país sobre las demás literaturas europeas, entre ellas, también la española. Pero sus equilibrados juicios, aunque no siempre acertados, como en el caso de Tirso por ejemplo, sobre el teatro del Siglo de Oro español y sobre la comedia nueva que aún gobernaba los escenarios españoles del XVIII, no se hallaban motivados de ningún modo por un prejuicio enraizado durante siglos contra la cultura española, la cual por el contrario había asimilado perfectamente. No se olvide que el napolitano de ningún modo desecha de manera genérica la producción dramática del período barroco, rescatando no pocos aspectos del teatro de Lope, Calderón (ver Quinziano, 2004) y, de modo especial, de los autores de la llamada escuela calderoniana, sobre todo Solís y Moreto
} 
avemmo in Genova nella vostra casa l'anno 1779, e ciò fo tanto più di buon animo, quanto che vi ho trovato incidentemente citato nell'originale (Opuscoli : 3-4; los subrayados son nuestros $)^{42}$.

El traductor italiano explicitaba en su carta-dedicatoria los propósitos que habían promovido la traducción de la comedia de su amigo español. En esta misiva, en la que los tonos respetuosos no logran esconder la evidente animosidad hacia el abate catalán, es posible reconocer la clave de lectura de su labor traductora para trazar a partir de ella un valioso instrumento de batalla ideológica y cultural y al mismo tiempo de autolegitimación personal como crítico teatral. No sorprenden, por tanto, las no pocas modificaciones llevadas a cabo por el napolitano en las últimas escenas, al aproximarse con cierta libertad al texto de Moratín, revelando la clara intención de apropiarse del texto original para actualizar la polémica con sus adversarios y denostadores españoles, quienes lo acusaban de hispanófobo y enemigo de la cultura hispánica, y legitimarse ante ellos como amplio conocedor y defensor del drama español.

Si es verdad, como evoca la carta-dedicatoria, que Lampillas había sido citado en el texto en clave irónica por Moratín $(\mathrm{CN}, 62)$, Signorelli, consciente del valor y de la temática que exhibía la pieza de su entrañable amigo, como se deduce de la carta al abate Placido Bordoni que abre el volumen (Opuscoli, IV: XIII) ${ }^{43}$, no desaprovechó la ocasión para arrojar nuevas acusaciones a Llampillas, a quien recuerda como el autor de "un Saggio apologetico del nostro teatro contro del Napoli-Signorelli, e della sua Storia de' teatri in sei volumi, in cui mostrerò la di lui ignoranza non essere minore di della di Giovanni Racine" (CNi, 43), y por tanto identificado de modo directo en la versión italiana al don Hermógenes moratiniano. A este respecto significativa resulta la manipulación del texto por parte del erudito partenopeo, quien, autocitándose y al aludir directamente de modo despectivo a sus tres adversarios, altera los diálogos finales de la comedia, acentuando al mismo tiempo los rasgos negativos que caracterizan a Don Hermógenes, prototipo del pedante vaniloquente:

D. Hermógenes-. (...) bien que yo estoy D. Ermogene-(...) Io però sto scrivendo da più anni escribiendo ahora una Apología del Teatro ${ }^{44}$, analisi, un Saggio y la citaré con elogio. Diré que hay otras in alcune cartucce, letterine, ed apologetico del nostro

\footnotetext{
42 Nótese el claro tono polémico que caracteriza la citada carta-dedicatoria: en ella el napolitano, consciente de los contenidos de la pieza traducida, orientados a poner en discusión el modelo teatral aún imperante, encuentra una preciosa ocasión para atacar nuevamente a García de la Huerta y a Ramón de la Cruz, quienes a su vez, tan sólo algunos años antes, se habían felicitado con el jesuita expulso por las consideraciones que organizaban su Saggio storico-apologetico contra los eruditos italianos y, de modo especial, contra Napoli Signorelli. Asimismo, como puede observarse, no pierde ocasión en cuanta oportunidad se le presenta para achacarle a Llampillas su lejanía física $\mathrm{y}$, por tanto, su escaso conocimiento, de los teatros españoles, poniendo en discusión tanto la fiabilidad como las fuentes de los que derivan los juicios vertidos por el catalán. Por último, Signorelli no puede ocultar su satisfacción frente al hecho de que Llampillas se encontrase "incidentemente citato" en el texto de Moratín, como indica en la carta: sin duda dicha inclusión, en el cuadro de las animadas polémicas ítaloespañolas del período, representaba para el italiano una pública legitimación de sus estudios y publicaciones y al mismo tiempo un prestigioso aval, como el que le llegaba de su amigo Moratín y que el hispanista napolitano, hombre vanidoso, no estaba dispuesto ciertamente a desaprovechar.

43 Placido Bordoni, erudito, historiador y literato veneciano (1736-1821), cultivó la poesía en latín e italiano y tradujo, entre otros, a Plinio, el Viejo y Cicerón, además de diversos dramas franceses. En la dedicatoria que el crítico italiano le envía al abate véneto y que abre el cuarto volumen de sus Opuscoli Vari, aquél le comenta cómo Leandro Moratín "riprenda acconciatamente i difetti del teatro nazionale appalesandosi vero amator della patria, a differenza di certi mercenari impostori italiani e spagnuoli, i quali tradiscono la verità (...)"(Opuscoli, IV: XIII).
} 
teatro contro del Napoli-peores; diré que si no guarda reglas ni della sua Storia de' teatri in sei autor era un grande hombre; callaré sus defectos... $(\mathrm{CN}$, 61)

porrò
Signorelli, $e$

conexión consiste en que el volumi, in cui mostrerò la di lui ignoranza non essere minore di quella di Giovanni Racine, scrittore imbecille $e$ insipido ${ }^{45}$ della Fedra $e$ dell'Atalia $e$ lo porrò per prologo davanti ad una collezione delle nostre commedie e fra esse in

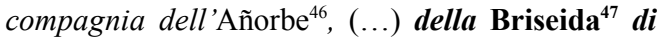
Ramón de la Cruz, dell'Agamennone ${ }^{48}$, di Huerta, e del Koulican di Cama cho, darò luogo al vostro Assedio di Trabisonda, facendone l'elogio al pari delle nominate. Dirò che ve ne sono delle peggiori citate dal Lampillas come eccellenti. Dirò che se non vi sono osservate le regole, se non vi è connessione, questo è, come dice il grande Vicente Huerta, perché un grande ingegno e non bada a quelle bagattelle; tacerò tutti i suoi difetti, e la al pari del Manolillo ${ }^{49}$ del rinomato La Cruz $(\mathrm{CNi}$, 43-44; las negritas y los subrayados son nuestros).

Si en La comedia nueva su autor alude al problema de la representación dramática, plasmando en su obra un valioso ejemplo de metateatro, Signorelli se aleja parcialmente del texto original al personalizar en su versión italiana la polémica teatral, realimentándola y al mismo tiempo actualizándola, lo que en cierto modo dispersa y prolonga el ritmo del desenlace en el texto. Como se desprende de los ejemplos recién aludidos, no son pocos lo cambios operados por el traductor en estos diálogos conclusivos, en las que destacan una mayor acentuación del rasgo caricaturesco y del perfil de los caracteres de algunos

\footnotetext{
${ }^{44}$ Aunque se cuida de citarlo directamente, es evidente la alusión de Leandro Moratín alEnsayo Apologético de Llampillas, cuyos volúmenes habían comenzado a publicarse algunos años antes, a partir de 1778 , siendo editados sucesivamente en español, con traducción de Josefa Amar y Borbón, en los primeros años ochenta.

${ }^{45}$ Estos son precisamente los epítetos con los que García de la Huerta en el Prólogo a su Theatro Hespañol (1785-86) atacó al célebre dramaturgo francés, por lo que la referencia en clave de polémica es más que obvia.

46 Tomás de Añorbe y Corregel (1686-1741), autor de farsas, comedias de figurón y tragedias en los primeros decenios del XVIII, que alcanzó cierto éxito y popularidad con la comedia de santos Princesa, ramera y mártir. Santa Afra, y con su tragedia El Paulino (1740), a la que alude el napolitano en su Storia Critica.

${ }^{47}$ Sobre la 'zarzuela heroica' La Briseida (1768) de Ramón de la Cruz véase el largo comentario, decididamente negativo, que el napolitano trazó en su Storia dei teatri (IX: 196-207). En las páginas dedicadas al análisis de la Briseida de Ramón de la Cruz, Signorelli había acomunado también al autor madrileño on el recién citado Añorbe, argumentando en tono irónico que "i critici nazionali decideranno qual siesi più scempiato componimento del secolo XVIII, se questa Briseida o il Paolino di Añorbe y Corregel”, (Storia, 1813, IX: 207).

48 Se refiere a la tragedia Agamenón vengado (1779), traducción de la famosa pieza de Sófocles, Electra, emprendida a través de la adaptación que había hecho Pérez de Oliva, de quien Huerta tomó además el título. A excepción de los primeros intentos orientados a establecer un modelo trágico según las reglas del arte -Nicolás de Moratín, Cadalso y López de Ayala- sumamente crítica fue su concepción de las tragedias en el XVIII español, e incluso, al referirse a los citados casos de sus amigos y contertulios de la Fonda de San Sebastián, no faltaron las observaciones críticas (Storia 1813, IX: 61-94). Sobre el modelo de tragedia en Signorelli véanse las páginas que le hemos dedicado en un estudio reciente (Quinziano 2004: 160-163).

${ }^{49}$ El sainete Manolo, como bien recuerda el mismo Signorelli, constituye una sátira de la tragedia neoclásica y de los defensores del clasicismo: "simile insipida farsaccia fu di mettere in ridicolo gli scrittori di tragedie e l'osservanza delle unità”, señala en su Storia critica de’ teatri (Storia, IX: 191).
} 
personajes (Hermógenes/Ermogene y Mariquita/Rosina, fundamentalmente). Del mismo modo más insistentes devienen las alusiones directas a los detractores y adversarios del traductor italiano, incorporados en el texto como ejemplos emblemáticos del mal gusto, del desarreglo artístico, de la vaniloquencia y la soberbia imperante en los escenarios y que con notable acierto Moratín había personificado en la figura del presumido don Hermógenes.

\section{FinaL}

A este punto se imponen unas breves notas conclusivas. La traducción de los textos moratinianos llevada a cabo por Napoli Signorelli, además de brindarnos una confirmación de la estrecha relación de amistad y estima recíproca que vinculó a ambos escritores, constituyen un notable ejemplo de los provechosos contactos culturales y literarios entre España e Italia durante los últimos decenios del XVIII y principios del XIX. La versión italiana de la Comedia Nueva, por lo que atañe al nivel lingüístico, sin negar la existencia de algunas trasposiciones al italiano de hispanismos y de algunos contados ejemplos de imprecisión en ámbito léxico, se nos revela bastante respetuosa del texto original, testimoniando el óptimo conocimiento que el dramaturgo italiano poseía tanto del idioma español, como así también de los propósitos de reforma ampliamente expuestos en la pieza con los que el italiano se solidariza. Si la cuestión de la decadencia del teatro en España y la urgencia de reformarlo constituye el eje central del texto moratiniano, ya que- como afirma don Pedro- "el teatro influye inmediatamente en la cultura nacional" ( $\mathrm{CN}, 56)$, el crítico napolitano intuyó además la presencia de los otros núcleos temáticos que organizan la pieza, como la educación femenina, el valor de la amistad, el contraste pedante/hombre de bien, etc., aspectos de ningún modo desdeñables en el horizonte cultural e ideológico del pensamiento de los ilustrados.

Napoli Signorelli, apasionado estudioso de la cultura y del teatro de la península ibérica, captó perfectamente la especificidad de la comedia de su amigo, al igual que los perfiles caracteriales de los personajes y el afán de reforma del que era portador dicho modelo teatral, por él concebido como valiosa "scuola di buoni costumi e di buon gusto" $(\mathrm{CNi}, 40)$. El literato napolitano comulgó plenamente con dichos principios y se empeñó en difundirlos en la Italia del Settecento, aunque la recepción del drama moratiniano y de sus otras versiones italianas en los escenarios de la península fue en cambio más bien modesta, entre otros aspectos, porque determinados componentes temáticos y de modo especial, como se ha observado con razón, "ciertos detalles de la ironía moratiniana" (Pérez Magallón 1994: 95), más allá de los esfuerzos del crítico partenopeo por adecuarlos al teatro italiano, resultaban de difícil comprensión fuera de su específico contexto cultural.

Ahora bien, si el italiano captó el propósito de la pieza del dramaturgo madrileño, introdujo no obstante determinadas modificaciones en el texto -ciertamente no de escaso relieve o "di poca importanza" (CNi, 53, nota 1), como en cambio se esforzó en poner de realce el mismo traductor-, principalmente orientados a acentuar la vertiente cómica y satírica de algunos de los personajes. Del mismo modo, consciente del valor polémico que exhibía la comedia moratiniana, se apropia del texto español con el propósito de proseguir y actualizar la polémica cultural contra los que denostaban la fórmula que habían sancionado los neoclásicos, personalizando de este modo su batalla cultural orientada a la reforma del teatro, y que ha llevado a Mariutti a hablar de "desahogo de una ira mal contenida del traductor" (1960: 782). 
Es evidente que el texto era más fácilmente descifrable para el espectador y el lector español que el italiano, aunque algunos de los contenidos que vertebran la pieza del madrileño se hallaban incorporados a los debates que los partidarios de la nueva estética llevaban a cabo en la Italia del período. El mismo Moratín era consciente de ello, al advertir a principios de 1796, o sea pocos meses después que se publicase la versión de Signorelli, que no era conveniente que la obra "se representara sin que una mano maestra la acomodase a este teatro y la vistiese al traje del país" (Obra póstuma, II: 196) ${ }^{50}$. Desde esta perspectiva es fácil suponer que el traductor italiano se hallaba más interesado en la publicación de su versión del texto moratiniano para proseguir su batalla -estética y personal- que en su eventual representación en los escenarios italianos, consciente por lo demás de las dificultades que, al centrarse en una temática estrechamente vinculada al debate teatral en España y por tanto, ajena a los códigos culturales y a los patrones de referencia de los aficionados de la Italia de finales del Settecento, exhibía una pieza como la Comedia nueva.

Huelga decir por último que Signorelli llevó a cabo la traducción de La Commedia nuova en el período que va desde inicios de 1793 hasta principios de 1795, coincidiendo parcialmente con la presencia en Nápoles del comediógrafo español, quien, como es notorio, transcurrió algunos meses en la ciudad partenopea, desde octubre de 1793 hasta el marzo del año siguiente. Es natural suponer, pues que Moratín, huésped en aquellos meses del amigo napolitano, haya sido interpelado por éste en varias ocasiones, durante los frecuentes encuentros que ambos mantuvieron en aquellos meses, sobre la versión italiana que éste se hallaba redactando, y que aquél haya aprobado las modificaciones y los añadidos sugeridos por su amigo italiano, aunque no disponemos de documentos que puedan atestiguarlo.

Fuese como fuese, no cabe duda de que Signorelli acabó apropiándose parcialmente del texto del dramaturgo español para convertirlo en un instrumento personal en su batalla cultural, erigiéndolo en un valioso instrumento de autolegitimación ante aquéllos que, injustamente, le acusaban de menoscabar y ofender la cultura española. Ello no le impidió, sin embargo, reconocer la importancia de la traducción como canal privilegiado de difusión y asimilación intercultural y vehículo de aproximación y reconciliación entre ambas penínsulas, consciente del hecho de que, como ponía de relieve en una carta redactada en 1783, poco antes de regresar definitivamente a su ciudad natal,

gli spagnuoli leggono poco i libri italiani che non contengono panegirici della letteratura spagnuola, e gli italiani, che qui sono [o sea que residen en España] per lo più attendono alla fortuna e non alla letteratura (cit. en Mininni 1914: 302).

Es sobre todo en dicha perspectiva que entendemos debe ser concebida y examinada la versión italiana de La comedia nueva, en la cual, del mismo modo que en las restantes traducciones que efectuó de las piezas de Moratín, el erudito napolitano se propuso traducir el texto -según le confesaba en su dedicatoria al abate Bordón-, procurando "d'imitarl[o] signorilmente", pero sin por ello "trascriverl[o] da schiavo" (Opuscoli, IV: XI).

\footnotetext{
${ }^{50}$ Cabe recordar que estas dificultades de todos modos no impidieron que, además de la traducción del literato napolitano, la pieza moratiniana fuese volcada al alemán en 1800 y al francés tres años más tarde.
} 


\section{REFERENCIAS BIBLIOGRÁFICAS}

ANDIOC, R. (1982): "El teatro en el siglo XVIII”, en J. M. Díez Borque (ed)., Historia de la literatura española, Madrid, Taurus, 4 vols., vol. III., Siglos XVII-XIX, pp. 199-290.

ANDIOC, R. y COULON, M. (1996): Cartelera madrileña del siglo XVIII.(1708-1808), Tolosa, Presses Universitaires du Mirrail, 2 vols.

BIGI, E. (1960): "Nota introduttiva a P. Napoli Signorelli”, Dal Muratori al Cesarotti, Milán, Ricciardi, pp. 587-643.

CADALSO, J. (1990): Cartas marruecas-Noches lúgubres, ed. de J. Arce, Madrid, Cátedra.

CALDERA, E. (1980): "Pietro Napoli Signorelli, traduttore di Moratín", Studi di letteratura italiana in onore di Fausto Montanari, Génova, Il Melangolo, pp. 149-60.

CASO GONZÁLEZ, J. M. (1992): "La tertulia de San Sebastián y la poesía arcádica italiana", en Italia e Spagna nella cultura del Settecento, Roma, Accademia dei Lincei, pp. 172-84.

CIAN, V. (1896): Italia e la Spagna nel secolo XVIII. Giovambattista Conti e alcune relazioni letterrarie fra l'Italia e la Spagna nella seconda metà del Settecento. Torino: Lattes.

COE, A. M. (1935): Catálogo bibliográfico y crítico de las comedias anunciadas en los periódicos de Madrid desde 1661 hasta 1819, Baltimore, The Johns Hopkins University Press.

COULON, M. (1994): "D. Ramón de la Cruz y las polémicas de su tiempo",Ínsula, 574, pp. 9-12.

COULON, M. (1995): "El sainete como género" y "Originalidad y significado de Ramón de la Cruz", en G. Carnero (coord.), Historia de la literatura española. 6: Siglo XVIII (1), Madrid, Espasa Calpe, pp. 328-335 y 335-347, respectivamente.

DOMÍNGUEZ ORTÍZ, A. (1983): "La batalla del teatro en el reinado de Carlos III". Anales de Literatura Española, 2, pp. 177-96; 3 (1984), pp. 107-284.

DOWLING, J. (1970): "Estudio sobre La comedia nueva", en L. F. de Moratín, La comedia nueva, ed. de J. Dowling, Madrid, Castalia, pp. 43-63.

Effemeride Letterarie, Roma, 1780-1783.

FABBRI, M. (1992): "I gesuiti espulsi e la polemica sulla traduzione poetica spagnola. L'opera di Giambattista Conti', en Italia e Spagna nella cultura del Settecento, Roma, Associazione Nazionale dei Lincei, pp. 145-162

FARINELLI, A. (1929): Italia e Spagna, Turín, Fratelli. Bocca.

FERNÁNDEZ DE MORATÍN, L. (1792): La comedia nueva. Comedia en dos actos, em prosa, representada en el Coliseo del Príncipe el 7 de febrero de 1792 (Madrid, Benito Cano, 1792). Sigla: $C N$

FERNÁNDEZ DE MORATÍN, L. (1795): La commedia nuova. Commedia in due atti in prosa tradotta dallo spagnuolo da P. Napoli Signorelli, en Opuscoli Vari, IV vol. (Nápoles, Stamperia Orsiniana, 1795, pp. 1-54). Sigla: CNi 
FERNÁNDEZ DE MORATÍN, L. (1867-1868): Obras póstumas de D. Leandro F. de Moratín, publicadas de Orden y a expensas del Gobierno de S. M., ed. de J. Hartzenbusch, Madrid, Rivadeneyra, 3 vols.

FERNÁNDEZ DE MORATÍN, L. (1944): Obras de Don Nicolás y Don Leandro Fernández de Moratín, Ed. B. Aribau, Madrid, Atlas (BAE: II), Sigla: Obras

FERNÁNDEZ DE MORATÍN, L. (1970): La comedia nueva, ed. de J. Dowling, Madrid, Castalia.

FERNÁNDEZ DE MORATÍN, L. (1973): Epistolario, ed., introducción y notas de R. Andioc, Madrid, Castalia, Sigla: Epistolario.

FERNÁNDEZ DE MORATÍN, L. (1994): La Comedia nueva. El sí de las niñas, ed. de J. Pérez Magallón, Barcelona, Crítica. Sigla: CN.

FERNÁNDEZ DE MORATÍN, L. (1995): Poesías completas (poesías sueltas y otros poemas), (ed.), de J. Pérez Magallón, Barcelona, Sirmio-Quaderns Crema.

FERNÁNDEZ DE MORATÍN, L. (1996): Il vecchio e la giovane [El viejo y la niña]. Traducción de P. Napoli Signorelli, ed. de B. Tejerina, Nápoles, Liguori.

GARCÍA DE LA HUERTA, J. (1783-85): Cartas sobre la Italia, Bolonia (B. Nacional Madrid. Mss: 6482-83).

GARCÍA DE LA HUERTA, V. (1785-86): "Prólogo”, en Theatro Esphañol, Madrid, Imp. Real, pp. VII- XXIII.

HEMPEL, W. (1965): "Per la storia delle polemiche fra Bettinelli, Tiraboschi, NapoliSignorelli e i gesuiti spagnoli", en Problemi di lingua e letteratura italiana del Settecento (Atti IV Congresso Associazione Internazionale per gli studi di lingua e letteratura italiana; Magunza y Colonia: 28 abril -1 mayo 1962), Wiesbaden, Verlag, 1965, pp. 115-120.

LAFARGA, F. (1992): Traducción y teatro en el siglo XVIII español [1986-87], en D. T. Gies y Russell P. Sebold (ed.), Historia y crítica de la literatura española (al cuidado de F. Rico). 4.1 Ilustración y neoclasicismo. Primer Suplemento, Barcelona, Crítica, pp. 78-84.

LAFARGA, F. (1997): El teatro europeo en la España del siglo XVIII, Universidad de Lérida.

LAFARGA, F. (ed.) (1999): La traducción en España (1750- 1830). Lengua, literatura, cultura, Universitad de Lérida.

LIVERANI, E. (1995): "La difesa del teatro barocco spagnolo di Francisco Javier Llampillas”, en Intersezioni: Spagna e Italia dal Cinquecento al Settecento, Roma, Bulzoni, pp. 125-148.

LLAMPILLAS, J. (1782-84), Saggio Storico-Apologetico della leteratura spagnuola contro le pregiudicate opinioni di alcuni moderni Scrittori Italiani, Génova, Repetto in Canneto, 1778-1781, 6 vols. Ed. española: Ensayo históricoapologético de la literatura española, Zaragoza, Miedes, 1782-84.

MARAVALL, J. A. (1988): "Política directiva en el teatro ilustrado", en Coloquio internacional sobre el teatro español del siglo XVIII, Abano Terme, Piovan, pp. 11-29. 
MARIUTTI DE SÁNCHEZ RIVERO, A. (1960): "Un ejemplo de intercambio cultural Hispano-Italiano en el siglo XVIII: Leandro Fernández de Moratín y Pietro Napoli Signorelli", Revista de la Universidad de Madrid, IX, pp. 763-808.

MATTIOLI, E. (2001): "La teoria della traduzione in Italia fra Settecento e Ottocento: le linee guida", en G. Catalano y F. Scotto (eds.), La nascita del concetto moderno di traduzione, Roma, Armando, pp. 88-101.

MIGUEL Y CANUTO; J. C. de (1996): "Voces españolas, ecos italianos: los jesuitas expulsos y la polémica sobre el teatro barroco", en J. M. Sala Valldaura (ed.), $E l$ teatro español del siglo XVIII, Universitdad de Lérida, 2 vols., II, pp. 625-652.

MININNI, C. G. (1914): Pietro Napoli Signorelli: vita, opere, tempi, amici, Città di Castello, Lapi.

NAPOLI SIGNORELLI, P. (1774): Satire di Pietro Napoli Signorelli. Dedicate al Sig. D. Muzzio Zona, primo medico di S. M. Cattolica, e Presidente del protomedicato, Génova, Stamperia Gesiniana (incluido también en Opuscoli Vari, II, pp. 1-127).

NAPOLI SIGNORELLI, P. (1783): Discorso storico-critico. Da servire di lume alla Storia Critica de' Teatri e di Risposta all'autore del Saggio Apologetico, Nápoles, Amato Cons, a spese di Michele Stasi.

NAPOLI SIGNORELLI, P. (1792-95): Opuscoli Vari, Nápoles, Orsino, 4 vols. Sigla: Opuscoli.

NAPOLI SIGNORELLI, P. (1801): Elementi di poesia drammatica. Di Pietro Napoli Signorelli, Milán, s.e.. Sigla: Elementi

NAPOLI SIGNORELLI, P. (1804-1805): Delle migliori tragedie greche e francesi. Traduzioni ed analisi comparative di P. Napoli Signorelli, Milán, Stamperia e Fonderia al Genio, 3 vols.

NAPOLI SIGNORELLI, P. (1810-18112): Vicenda della coltura delle due Sicilie, Nápoles, Flauto [1784-86], 6 vols.

NAPOLI SIGNORELLI, P. $\left(1813^{3}\right)$ : Storia critica dei teatri antichi e moderni, Nápoles, Orsino [ 1777], 10 vols. Sigla: Storia

PELLISIER, R. (1918): The Neo-Classic Movement in Spain during the XVIII Century, California, Stanford University.

QUINZIANO, F. (2001): "La commedia nuova (1795): P. Napoli Signorelli, traduttore e diffusore del teatro 'ilustrado' di L. Fernández de Moratín”, en G. Catalano y F. Scotto (eds.), La nascita del concetto moderno di traduzione, Roma, Armando, pp. 259-87.

QUINZIANO, F. (2002): "Pedro Napoli Signorelli y Leandro Fernández de Moratín: amistad, afinidades e influjos literarios", en Ehumanista. Journal of Iberian Studies (University of California) 2, pp. 188-236.

QUINZIANO, F. (2003): "Caro soggiorno: Pedro Napoli Signorelli en la España del XVIII", en Dieciocho. Hispanic Enlightenment (Univ. of Virginia; USA), 26.2, pp. $241-264$.

QUINZIANO, F. (2004): "Napoli-Signorelli y el teatro áureo en el XVIII: la crítica a las tragedias de Calderón", Philologia Hispalensis, vol. XVIII, pp. 151-179.

RÍOS CARRATALÁ, J. A. (1987): Vicente García de la Huerta (1734-1787), Badajoz, Diputación Provincial. 
ROSSI, G. C. (1974): Leandro Fernández de Moratín. Introducción a su vida y obra, Madrid, Cátedra.

SÁNCHEZ BLANCO-PARODY, F. (2002): El Absolutismo y las Luces en el reinado de Carlos III, Madrid, Marcial Pons.

SEMPERE Y GUARINOS, J. (1969): Ensayo de una biblioteca española de los mejores escritores del reynado de Carlos III [Madrid, Imprenta Real, 1785-89]; ed. facsímil: Madrid, Gredos, 6 vols.

SORIANO PÉREZ-VILLAMIL, E. (1980): España vista por historiográfos y viajeros italianos (1750-1799), Madrid, Narcea.

TEJERINA, B. (1995): “El Calderero de San Germán de Gaspar Zavala y Zamora traducido al italiano por Pietro Andolfati”, en E. Giménez, J. A. Ríos y E. Rubio (eds.), Relaciones culturales entre Italia y España, Alicante, Universidad de Alicante, pp. 173-188.

TEJERINA, B. (1996): “Introduzione”, en L. F. de Moratín, Il Vecchio e la giovane, ed. de B. Tejerina, Nápoles, Liguori, pp. 7-77.

URZAINQUI, I. (1991): "Hacia una tipología de la traducción en el siglo XVIII: los horizontes del traductor", en $\mathrm{M}^{\mathrm{a}} \mathrm{L}$. Donaire y F. Lafarga (eds.), Traducción y adaptación cultural: España-Francia, Universidad de Oviedo, pp. 623-638. 